\title{
The MIS 5 palaeoenvironmental record in the SE Mediterranean coast of the Iberian Peninsula (Río Antas, Almería, Spain)
}

T. Torres ${ }^{1}$, J. E. Ortiz ${ }^{1}$, A. M. Blázquez ${ }^{2}$, B. Ruiz Zapata ${ }^{3}$, M. J. Gil ${ }^{3}$, T. Martín ${ }^{3}$, and Y. Sánchez-Palencia ${ }^{1}$

${ }^{1}$ Laboratory of Biomolecular Stratigraphy, E.T.S.I. Minas y Energía, Universidad Politécnica de Madrid, C/ Ríos Rosas 21, Madrid 28003, Spain

${ }^{2}$ Environmental and Marine Sciences Research Institute, Catholic University of Valencia C/Guillem de Castro 94, 46003 Valencia, Spain

${ }^{3}$ Dpto. Geología, Facultad Ciencias, Universidad Alcalá de Henares, Campus Universitario, Universidad Alcalá, 28871 Alcalá de Henares, Madrid, Spain

Received: 13 July 2015 - Accepted: 12 August 2015 - Published: 26 August 2015

Correspondence to: J. E. Ortiz (joseeugenio.ortiz@upm.es)

Published by Copernicus Publications on behalf of the European Geosciences Union.

The MIS 5

palaeoenvironmental record in the SE Mediterranean coast

T. Torres et al.

Title Page

Abstract

Introduction

Conclusions

References

Tables

Figures

14

4

Back

Full Screen / Esc

Printer-friendly Version

Interactive Discussion 


\section{Abstract}

Landwards of a MIS5 bar, a borehole core (SRA) was analyzed to establish the relationship between the lagoonal record and the raised beach deposits in the surroundings of the Antas river mouth and to reconstruct the Pleistocene palaeoenvironmental evo5 lution of the southern Mediterranean coast of the Iberian Peninsula. 63 samples were recovered for amino acid racemization dating, 86 samples for sedimentological and paleontological determination, 37 samples for pollen identification and 54 for biomarker analysis. AAR revealed that the borehole record contains MIS11, MIS6 and MIS5 deposits, the latter extensively represented. During the end of MIS6 and MIS5, a sand barrier developed and created a shallow lagoon with alternating terrestrial inputs this process being common in other Mediterranean realms. Litho- and biofacies allowed the identification of distinct paleoenvironments through time, with the presence of a lagoonal environment alternating with alluvial fan progradation. Biomarkers indicated constant input from terrestrial plants, together with variable development of aquatic 15 macrophytes. The palynological content allowed the reconstruction of the paleoclimatological conditions during MIS6 and 5, with evidence of seven scenarios characterized by alternating arid and relatively humid conditions.

\section{Introduction}

In many areas of the Mediterranean coast - Spain, Morocco, Tunisia - the current 20 morphology appears as a series of cliffs where Alpine tectonics-linked parallel ranges reach the sea alternating with lagoons and wetlands. Some of the Quaternary coastal deposits of the Spanish Mediterranean realm have been studied, mostly focusing on raised marine deposits and addressed faunal remains and radiometric ages (Goy et al., 1986; Hillaire-Marcel et al., 1986; Causse et al., 1993; Zazo, 1999; Zazo et al., 2003; Dabrio et al., 2011) and amino acid chronology (Hearty, 1986, 1987; Hearty et al., 1986; Torres et al., 2000a, 2010a; Ortiz et al., 2004a). Unfortunately, raised marine
CPD

11, 3897-3936, 2015

The MIS 5

palaeoenvironmental record in the SE Mediterranean coast

T. Torres et al.

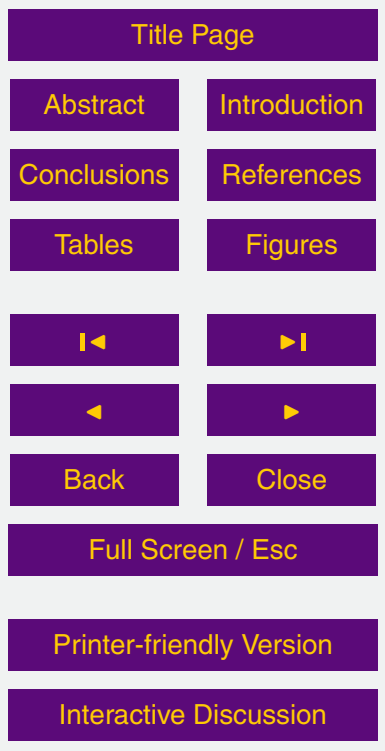


deposits offer limited paleoenvironmental information because their coarse-very coarse grain size does not allow the preservation of most paleobiological (pollen, ostracods and foraminifers) and geochemical (biomarkers) signals.

Other authors have examined the lagoonal records (Collado and Robles, 1983; 5 Usera et al., 2002, 2006; Ferrer et al., 2005; Blázquez and Usera, 2010; Ferrer y Blázquez, 2012) and pollen content of continental sequences (Pérez-Obiol and Julià, 1984; Fumanal and Dupré, 1986; Burjachs and Julià, 1994; YIl et al., 1994; Badal and Roiron, 1995; Carrión and Dupré, 1996; Carrión and van Geel, 1999; Carrión et al., 1999).

10 In this regard, the lagoonal record in the Antas river mouth area and associated raised marine deposits provide an interesting system to establish methodological work which allow the understanding of high stand sea level deposits through-time evolution in the Mediterranean realm, especially MIS5.

The Mediterranean coastline between the mouths of the Aguas and Antas rivers 15 has not been examined in detail. A number of raised marine deposits were previously sampled for the determination of a regional amino-stratigraphical framework (Torres et al., 2000a, 2010a). The lagoonal deposits that outcrop in this area have been studied by Pantaleón-Cano et al. (2003), who analyzed the pollen content, but the bizarre ${ }^{14} \mathrm{C}$ ages obtained precluded any realistic interpretation of the record. In 2007, a new $25 \mathrm{~m}$ borehore core (named SRA) was drilled.

Coastal marshes and mires, most representing the last evidence of the satellite basins that developed after the Alpine Orogeny Period, hold the best preserved paleoenvironmental signals. Lagoonal and marsh deposits appear along the Spanish Mediterranean coast in Peñíscola (Usera et al., 2006), Torreblanca (Collado and Rob25 les, 1983; Segura et al., 1997), Almenara (Blázquez and Rodríguez-Pérez, 2013), Jávea (Fumanal et al., 1993; Usera et al., 2002), Gandía and La Safor (Viñals, 1995a), Moraira (Viñals, 1995b), Albufereta-Alicante (Ferrer et al., 2005, Ferrer y Blázquez, 2012), and Roquetas de Mar (Pantaleón Cano et al., 2003). However, all these deposits have short sequences covering the Holocene. While longer Pleistocene sequences ap-

\section{CPD}

11, 3897-3936, 2015

The MIS 5

palaeoenvironmental record in the SE Mediterranean coast

T. Torres et al.

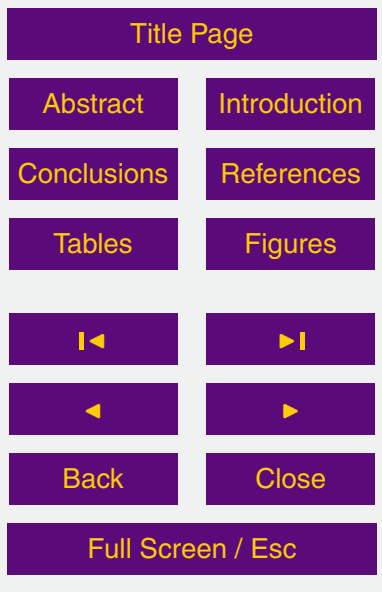

Printer-friendly Version

Interactive Discussion 
pear in the Elche Basin (Blázquez, 2005, Blázquez and Usera, 2010) and Pego Basin (Dupré et al., 1988; Mateu, 1989; Viñals et al., 1989; Hernández-Ruiz et al., 1993; Viñals and Fumanal 1995; Viñals, 1996; Mateu et al., 1997; Torres et al., 2013), sequences belonging to MIS5 are present as loosely cemented sands. Consequently, 5 the core recoveries are low and the grain size is not favorable for paleoenvironmental recording.

We therefore considered this deposit suitable for interpreting the paleoenvironmental evolution of the southern Mediterranean coast of the Iberian Peninsula. The aims of this study were as follows: (1) to establish the chronological framework through amino 10 acid racemization dating of the lagoonal deposits (SRA core); (2) to obtain paleoenvironmental information based on sedimentology and micropaleontology of a long MIS5 sequence; (3) to determine regional plant biomes and paleoclimatic variations based on pollen data; and (4) to address the biomes of the area by interpreting the biomarkers contained in the sediments.

\section{Geographical and geological setting}

\subsection{Geographical and physiographical framework of the study zone}

The SRA borehole was drilled in the Vera Basin, which is an inverted basin (Stokes, 2008) in the Internal Zone of the Betic Cordillera. The Garrucha village is placed on a hill slope capped with beach deposits of Pleistocene age lying uncomfortably on quasiazoic Pliocene delta sediments. The western side of the village ends abruptly due to a vertical cliff, which falls on a flat, almost endorheic, depression - El Salar - in which saline muds accumulate during flash-flood episodes that the Antas river cannot drain, as occurred on 28 September 2012.

This area around the mouths of the Aguas and Antas rivers hosts a series of
Pleistocene-age marine deposits that mark the eastern edge of the marine Vera Basin
CPD

11, 3897-3936, 2015

The MIS 5

palaeoenvironmental record in the SE Mediterranean coast

T. Torres et al.

\section{Title Page}

Abstract Introduction

Conclusions References

Tables Figures

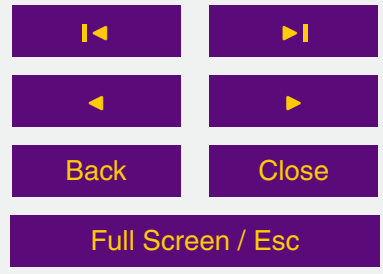

Printer-friendly Version

Interactive Discussion 
(Fig. 1), which can be age-correlated in spite of they were subjected to strong neotectonic processes (Torres et al., 2000a, 2006, 2010a, 2013).

In fact, in the immediate neighborhood of the SRA, a stripe representing an ancient barrier system (MIS5) and running parallel to the present day coastline is clearly visible 5 in Fig. 1. This stripe consist of gravel and coarse sands that are strongly carbonatecemented, and should protect the lagoonal area of SRA during MIS 5. These materials appear as foreshore dipping beds some decimeters thick. At some points, a number of beds dip backshore. Scattered Glycymeris sp. shells are visible, as well as some rare Persististrombus latus (sin. Strombus bubonius) representatives. Today the ancient bar

10 is occupied by a tourist center, but a section is still visible on each side of the road entering the resort.

\subsection{Biological setting of the area around the Antas river}

The area is placed in the "almeriense" sector of the "murciano-almeriense" chorological province (Rivas Martinez, 1988). The native plant species are resistant to drought and aridity, which occur during the summer and also in some winter-autumn months. Thus plant species have xerophytic characteristics, thus largely exposing soil and bed rock (Ferré Bueno, 1979).

The natural vegetation in the Almanzora valley falls in the climatic dominion of Quercus ilicis and Oleo-Ceratonion. The former holds Quercus ilex, Q. coccifera, Juniperus 20 phoenicea, Dhapne gnidium and Retama sphaenocarpa, although $Q$. ilex is scarce. In many areas, Pinus halepensis has disappeared or remains as scattered individuals, and in wetter zones isolated individuals of $P$. pinaster are found. In general, only subserial bushes belonging to the $Q$. ilex dominion are present: Rosamarinus officinalis, Cistus albidus, Rhamnus lyciocides, Genista umbelata, Ulex sp., and $R$. spaenocarpa. 25 In more severely degraded areas, only species of Thymus, Artesania glutinosa and Stipa tenacissima are detected.

In the western-most sierras, a variety of the $Q$. ilex grade was observed: the subgrade $Q$. Iusitanica-Acer monspesulamun granatensis attesting a wetter and colder

\section{CPD}

11, 3897-3936, 2015

The MIS 5

palaeoenvironmental record in the SE Mediterranean coast

T. Torres et al.

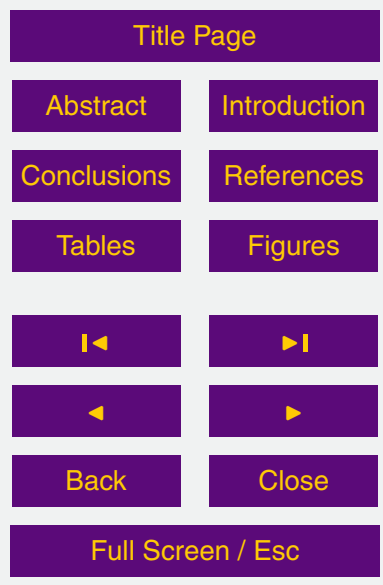

Printer-friendly Version

Interactive Discussion 
climate. Towards the eastern ends of the sierras there was a gradual change to the Oleo-Ceratonion grade, represented by $Q$. coccifera, Pistacia lentiscus, Ceratonia siliqua, Olea oleaster, and $P$. halepensis.

All these series showed profound degradation, which is linked to industrial activity 5 (mining and metalworking industry), agriculture, and grazing (Rodríguez Ariza, 1999).

\section{Material and methods}

The sampling work focused on the SRA of the Antas river (Fig. 1). This borehole was drilled for geotechnical studies on the right margin of the river, near its mouth, where the river incises $3.5 \mathrm{~m}$ into soft materials.

10 Ten kilometers upstream of the Aguas river mouth, the tufa deposits from Alfaix (ALF) outcrop. These were used only to check the results obtained in SRA. The tufa deposits consist of a $23 \mathrm{~m}$ thick sequence (Schulte et al., 2008), the bottom of which is $7 \mathrm{~m}$ above the present day Aguas river thalweg. Using U/Th dating, these authors dated the lowermost $13 \mathrm{~m}$ (approx.) of the sequence at $169 \pm 9 \mathrm{ka}$ and reported that it shows 15 a fluvial character, the uppermost part comprising a series of piled-up bioconstructed tufa barriers trapping fluvial and dominant slope deposits. The top of the sequence is $108 \mathrm{~m}$ a.s.l. and is dated at $>26 \pm 1 \mathrm{ka}$ (Schulte et al., 2008).

\subsection{AAR analysis}

To establish the chronology of the SRA record, we selected ostracod shells as they provided excellent results in former studies (Ortiz et al., 2004b, 2009). Similarly, ostracods were also sampled in three levels of the Alfaix fluvial terrace.

Ostracod specimens from various species were recovered, although only Cyprideis torosa representatives were included in the analysis because it was the only species present in all horizons. Only in one horizon of the SRA borehole (15 m depth) were Herpetocypris reptans representatives also collected. Thus, analytical samples from

\section{CPD}

11, 3897-3936, 2015

The MIS 5

palaeoenvironmental record in the SE

Mediterranean coast

T. Torres et al.

\section{Title Page}

Abstract

Conclusions

Tables

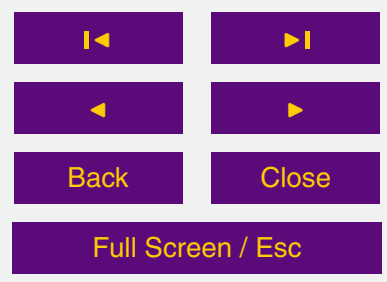

Printer-friendly Version

Interactive Discussion 
each bed contained only single monospecific $C$. torosa valves, except for SRA-1500. When possible, we performed seven analyses of the same bed. A total of 63 analytical samples from 11 horizons of the SRA borehole, and 16 analytical samples from three beds of the Alfaix fluvial terrace were examined (Table 1).

$5 \quad$ Ostracod valves were cleaned sonically in distilled deionized (DDI) water and rinsed in the same water to remove sediment. Some valves were also cleaned with a small brush under a binocular microscope to eliminate fine debris. In order to remove secondary organic molecules adsorbed to the shells, the valves were then submerged in $3 \%$ hydrogen peroxide $\left(\mathrm{H}_{2} \mathrm{O}_{2}\right)$ for $2 \mathrm{~h}$ following Kaufman (2000) and Hearty et 10 al. (2004).

Amino acid concentrations and ratios were quantified using HPLC, following the sample preparation protocol described by Kaufman and Manley (1998) and Kaufman (2000). This procedure involves sample hydrolysis, which was performed under an $\mathrm{N}_{2}$ atmosphere in $7 \mu \mathrm{L}$ of $6 \mathrm{M} \mathrm{HCl}$ for $20 \mathrm{~h}$ at $100^{\circ} \mathrm{C}$. The hydrolysates were evapo15 rated to dryness in vacuo, and then rehydrated in $7 \mu \mathrm{L} 0.01 \mathrm{M} \mathrm{HCl}$ with $1.5 \mathrm{mM}$ sodium azide and $0.03 \mathrm{mML}$-homo-arginine (internal standard). Samples were injected in an Agilent-1100 HPLC, equipped with a fluorescence detector. Excitation and emission wavelengths were programmed at $335 \mathrm{~nm}$ and 445, respectively. A Hypersil BDS C18 reverse-phase column $(5 \mu \mathrm{m} ; 250 \times 4 \mathrm{~mm}$ i.d. $)$ was used for the analysis.

Derivatization took place before injection by mixing the sample $(2 \mu \mathrm{L})$ with the precolumn derivatization reagent $(2.2 \mu \mathrm{L})$, which comprised $260 \mathrm{mM}$ isobutyryl-L-cysteine (chiral thiol) and $170 \mathrm{mM}$ o-phthaldialdehyde, dissolved in $1.0 \mathrm{M}$ potassium borate buffer solution at $\mathrm{pH} 10.4$. Eluent $A$ consisted of $23 \mathrm{mM}$ sodium acetate with $1.5 \mathrm{mM}$ sodium azide and 1.3 micro $\mathrm{M}$ EDTA, adjusted to $\mathrm{pH} 6.00$ with $10 \mathrm{M}$ sodium hydroxide and $10 \%$ acetic acid. Eluent B was HPLC-grade methanol and eluent $C$ consisted of HPLC-grade acetonitrile. A linear gradient was performed at $1.0 \mathrm{~mL} \mathrm{~min}^{-1}$ and $25^{\circ} \mathrm{C}$, from $95 \%$ eluent $A$ and $5 \%$ eluent $B$ upon injection to $76.6 \%$ eluent $A, 23 \%$ eluent $B$, and $0.4 \%$ eluent $\mathrm{C}$ at $\min 31$.

\section{CPD}

11, 3897-3936, 2015

The MIS 5

palaeoenvironmental record in the SE

\section{Mediterranean coast}

T. Torres et al.

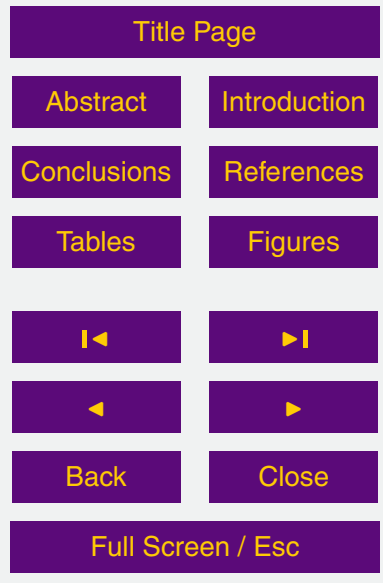

Printer-friendly Version

Interactive Discussion 
For the age calculation of SRA and ALF samples, aspartic acid and glutamic acid were chosen because they account for over ca. $50 \%$ of the amino acid content in most ostracod valves (Kaufman, 2000; Bright and Kaufman, 2011). The numerical age of each bed was determined by introducing the aspartic acid and glutamic acid $D / L$ values obtained in $C$. torosa individuals from the Alfaix terraces and the SRA borehole into the age calculation algorithms described by Ortiz et al. (2004b). The age of a single bed is the average of the numerical dates obtained for each amino acid D/L value measured in ostracods from that horizon. The age uncertainty is the standard deviation of all the numerical ages calculated from the amino acid $D / L$ values of each level.

10 We used the age calculation algorithms obtained in ostracods collected in central and southern Spain by Ortiz et al. (2004b) for the dating these deposits because a similar thermal history can be inferred for these areas, as they are all located in the Mediterranean climatic zone of the Iberian Peninsula, with a similar mean annual temperature. Likewise, the age calculation algorithms were established for the ostracod 5 species analyzed here (C. torosa and $H$. reptans), which show similar racemization rates for Middle and Lower Pleistocene localities (Ortiz et al., 2013). Thus DL ratios are directly comparable without any conversion factor.

\subsection{Sedimentology}

A total of 86 samples at $20-30 \mathrm{~cm}$ intervals were picked from the borehole core. These 20 samples were analyzed for sedimentological, micropaleontological (especially, ostracoda and foraminifera) and palynological studies. The sampling interval was chosen on the basis of major changes in sediment color, grain size, and the presence of chemicals (gypsum crystals), and macrofossils.

Totally dried samples were gently crushed, soaked, passed through a $62 \mu \mathrm{m}$ mesh 25 sieve, and analyzed under microscope. Some samples were resin-embedded to study the sand fraction mineralogy in a thin section.

\section{CPD}

11, 3897-3936, 2015

The MIS 5

palaeoenvironmental record in the SE Mediterranean coast

T. Torres et al.

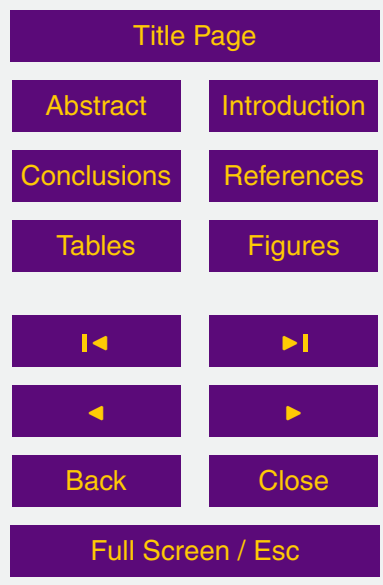

Printer-friendly Version

Interactive Discussion 


\subsection{Palynology}

A total of 37 samples were selected for palynological analysis. Pollen was extracted following standard protocols (Couteaux, 1977; Faegri et al., 1989; Girard and RenaultMiskovsky, 1969; Moore et al., 1991). The residuals were pollen-enriched through flota5 tion in Thoulet's dense liquor (Goeury and Beaulieu, 1979) and later placed in Eppendorf tubes and preserved in glycerin.

Pollen grains were read and counted following Cambon (1981): 42 rows in each sample. The number of pollen grains in the samples oscillated between 110 and 716, although in some samples the number was so low (10-20) that they appeared in the 10 pollen diagram as "presences". In these cases the number of identifiable taxa was greatly reduced (5 or lower).

Statistical analysis was done using the package OLEA (M. Arroyo unpublished), which is based on philosophy of the TILIA $^{\circledR}$ and TILIA-GRAPH ${ }^{\circledR}($ Grimm, 1987, 1992) packages.

15 In the samples with a statistically significant number of pollen grains, we built AP/NAP logs and analyzed the rarefaction (Birks and Lyne, 1992) to determine vegetation diversity.

In order to facilitate the interpretation of the data, we built a synthetic pollinic diagram, which included the most significant taxa (Pinus, Juniperus) in the spectrum, as well as the largest taxa clusters (Mesophilous, Mediterranean, Xeric, Steppic).

Finally, all the sampled were subjected to a PCA (Principal Component Analysis) using the Biplot application from Excel-Microsoft.

\subsection{Biomarker analyses}

A total of 54 samples were collected for biomarker analysis, coarse-grained sediments being discarded. $5 \mathrm{~g}$ of sediment per sample was dried at $50^{\circ} \mathrm{C}$ for $24 \mathrm{~h}$ and then ground with a mortar and pestle. Biomarkers were extracted in an accelerated solvent extractor (Dionex ASE 200) using dichloromethane/methanol $2: 1$ at 1500 psi and $175^{\circ} \mathrm{C}$ (after

\section{CPD}

11, 3897-3936, 2015

The MIS 5

palaeoenvironmental record in the SE Mediterranean coast

T. Torres et al.

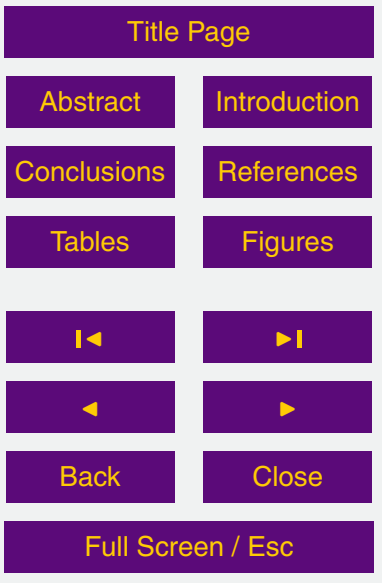

Printer-friendly Version

Interactive Discussion 
various tests, this temperature proved to be the optimum for the extraction of most biomarkers). The heating phase lasted $8 \mathrm{~min}$ and the static extraction time $5 \mathrm{~min}$.

The isolated lipid extract was concentrated to dryness using a rotary evaporator, then methlylated with trimethylsilyldiazomethane and methanol for $20 \mathrm{~min}$ and evaporated 5 with nitrogen. Samples were redissolved in $1 \mathrm{ml}$ of dichloromethane prior to analysis by gas chromatography (HP 6890) with a mass selective detector (HP 5973) equipped with an ATM-5 column $(250 \times 0.25 \mathrm{~mm} ; 0.20 \mu \mathrm{m})$. Helium was used as the carrier gas. The oven temperature was programmed from 60 to $300^{\circ} \mathrm{C}$ at $6^{\circ} \mathrm{C} \mathrm{min}{ }^{-1}$ and the injector was maintained at $275^{\circ} \mathrm{C}$. Components were identified with the Data Analysis program 10 and the Wiley mass spectral Library: $n$-alkane distributions were obtained from the GC/MS chromatograms of $m / z 57$. We focused our study on $n$-alkanes, though acids and ketones were also identified.

\section{Results}

\subsection{Chronology}

15 The $D / L$ values of aspartic acid and glutamic acid in the ostracod samples from the Alfaix tufa terraces and the SRA borehole are shown in Table 1. The ages obtained in the former were coincident with those reported by Schulte et al. (2008) using U/Th dating $(169 \pm 9$ and $148 \pm 8 \mathrm{ka})$, although the standard deviation of AAR ages obtained here was larger.

SRA ages, in agreement with Alfaix U/Th-dated tufa deposits, totally differed from the ages described by Pantaleón-Cano et al. (2003) for the lagoonal deposits of the mouth of the Antas River, namely: $8690 \pm 150 \mathrm{yr}$ at $22 \mathrm{~m}, 7730 \pm 100 \mathrm{yr}$ at $11 \mathrm{~m}$ depth, $8070 \pm 90 \mathrm{yr}$ at $10 \mathrm{~m}, 8210 \pm 250 \mathrm{yr}$ at $6.3 \mathrm{~m}, 6280 \pm 60 \mathrm{yr}$ at $5.8 \mathrm{~m}$. A single criticism of these data is that the ages, although supposedly not linked to laboratory errors in dating, are erratic because the sedimentation rate is unrealistic. According to our experience in Pego basin (Torres et al., 2013), these anomalous ${ }^{14} \mathrm{C}$ values can be

\section{CPD}

11, 3897-3936, 2015

The MIS 5

palaeoenvironmental record in the SE

\section{Mediterranean coast}

T. Torres et al.

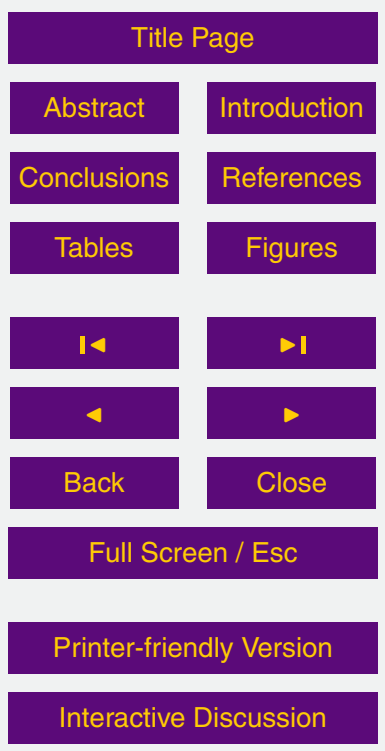


explained as recent contamination associated with ground-water circulation in nearshore aquitards in arid areas under a marine intrusion regime. In fact, the analysis of total carbon in bulk sediments is inappropriate because significant differences between the radiocarbon content of the bulk sediment and true age can arise (Olsson, 1986; 5 MacDonald et al., 1987; Lowe et al., 1988; Brown et al., 1989; Torres et al., 2010b). Pantaleón-Cano et al. (2003) dated a sample at $0.5 \mathrm{~m}$ of depth at $1390 \pm 100 \mathrm{BP}$; however, although appearing reliable, it seems somewhat too young as implies that the deep river incision should occurred in historical times.

The possibility of ostracod reworking from older deposits is unlikely because the 10 shells were not eroded, in some cases still being articulated. Furthermore, in some samples ostracods were found together with juvenile thin-shelled Cerastoderma glaucum representatives that were too fragile to be transported.

The AAR dating of the SRA record allowed us to determine that MIS11 (a single dating was obtained), MIS6 pro-parte, and MIS5 are represented. As the ages showed an uncertainty of about $25 \%$, the MIS5 sub-episode boundaries were refined on the basis of the palynological analysis and paleoenvironmental information derived from sedimentology. This implies that MIS6-MIS5e was displaced $80 \mathrm{~cm}$ upwards, and we were unable to differentiate between MIS5b and MIS5a.

\subsection{Sedimentology and fossil content}

20 The SRA core comprised mainly material of detrital origin, predominantly clay, silt, and marls (Fig. 2). Six lithologies were observed:

- Gm: Gravel $C=26-60 \mathrm{~mm}$ (poorly recovered from the core), with clasts of quartz, dolostone, limestone and metamorphic rocks, with variable amounts of heterometric quartz sand, abundant mica flakes, and red-brown lutites (matrix?).

- Gf: fine-grained gravel $(C=5 \mathrm{~mm})$ made of quartz and metamorphic rocks in a lutitic matrix with limonitized botroids (derived from pyrite), in which reworked marine microfossils were common.

\section{CPD}

11, 3897-3936, 2015

The MIS 5

palaeoenvironmental record in the SE Mediterranean coast

T. Torres et al.

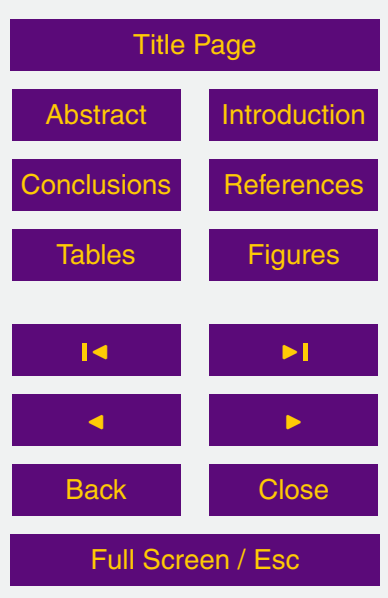

Printer-friendly Version

Interactive Discussion 
- SI: laminated medium-coarse grained quarzt sands, with metamorphic rock fragments. In outcrops, ripples and scattered charcoal fragments are visible. This is the only portion of the record visible on outcrops.

- Fs: carbonated sandy lutites (silt), with scarce scattered sand grains, locally iron oxide-stained.

- Fm: massive lutites (clay), with small amounts of fine-grained sand. Mica flakes are abundant.

- Mg: white-gray marls with lenticular and tabular gypsum crystals, limonitized plant stems and carbonate-cemented tubuli (plant roots?).

10 The mineralogy of the fraction coarser than $62 \mu \mathrm{m}$ (Table 2) confirmed that the local source of the sediments was metamorphic rocks (micaschists) and dolostones of Permo-Triassic age. The former are reflected in a myriad of mica flakes and quartz grains, most of them reworked from Pliocene marine silts and marls, as attested by large amounts of resedimented foraminifers from this age. There was a very small 15 contribution of mafic vulcanites of Neogene age.

Many samples contained foraminifers, with the exception of the following levels: $2300,1780-1600,1330-1240,790,1120-850 \mathrm{~cm}$. We separated the foraminifera species into two assemblages: autochthonous and allochthonous associations. The former holds indigenous specimens while the latter indicates reworked tests from older 20 strata (Pliocene). Most of the samples including foraminifers showed the allochthonous association. Only levels 2300, 1850, 1390-1360, 1180, 820, 700, 300-240 cm contained autochthonous foraminifers, the following being common: Elphidium excavatum (Terquem), Ammonia tepida (Cushman), Haynesina germanica (Ehrenberg). Other autochthonous foraminifers included Aubignyna perlucida (Heron-Allen and Earland), Elphidium williamsoni Haynes, Bulimina marginata D'Orbigny, and Bolivina sp.

The allochthonous association comprised planktonic (Globigerinoides ruber (D’Orbigny), Orbulina universa D'Orbigny, Globigerinoides sacculifer (Brady), Glo-

\section{CPD}

11, 3897-3936, 2015

The MIS 5

palaeoenvironmental record in the SE Mediterranean coast

T. Torres et al.

Title Page

Abstract

Conclusions

Tables

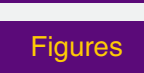

14

4

Back

Introduction

References

Figures

Full Screen / Esc

Printer-friendly Version

Interactive Discussion

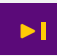

$\checkmark$

Close

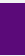

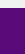

sion 
bigerinoides obliquus Bolli, Globigerina bulloides; D'Orbigny) and deep benthonic (Melonis pompilioides (Fichtel and Moll), Pullenia bulloides (D'Orbigny), Cibicides subhaidingeri Parr, Cibicides pseudoungerianus (Cushman), Legenina sp., Cancris auricula (Fichtel and Moll), Amphicorina scalaris Batsch, and Globocassidulina oblonga 5 Reuss.) foraminifers, together with some showing wide bathymetric distribution (Bulimina marginata D'Orbigny, Ammonia beccarii (Linné), and Nonion commune; D'Orbigny). This association is typical of Pliocene age and consistent with findings by Torres et al. (2000b).

This association was present between 2960 and $2840 \mathrm{~cm}$, but foraminifer tests did 10 not show evidence of reworking and therefore could be dated as Pliocene.

A large number of ostracod valves were recovered from almost all the samples, the presence of $C$. torosa being continuous along the entire length of the borehole. In general, the valves were well-preserved. This species is found in highly saline marshes, lagoons, and continental ponds, in waters with a wide range of salinity, varying from 0.5

15 to $60 \%$ (De Deckker, 1981). However, according to Carbonnel (1983), this ostracod has been found in waters with salinity up to $140 \%$. These observations imply that the valves reflect a wide range of hydrogeochemical conditions. Other ostracod genera, including $H$. reptans and llyocypris bradyi Sars, typical of water bodies with low salinity (De Deckker, 1981), were also recovered, together with $C$. torosa in some samples $(1500,1420,7000$, and $540 \mathrm{~cm})$.

Mollusks were scarce in the SRA and limited to levels $1390-1330 \mathrm{~cm}$, in which Cerastoderma sp. and Hydrobia $\mathrm{sp}$ and other bivalves were present. Likewise, we found bivalves and gastropods between 550 and $520 \mathrm{~cm}$ and also identified continental gastropods at $330 \mathrm{~cm}$.

\subsection{Biomarkers}

Lagoons and marshlands receive organic matter from autochthonous (phytoplankton, bacteria, aquatic macrophytes) and allochthonous (terrestrial plant debris, pollen) sources. Consequently, palaeoenvironmental changes are reflected in the biogeo-

\section{CPD}

11, 3897-3936, 2015

The MIS 5

palaeoenvironmental record in the SE Mediterranean coast

T. Torres et al.

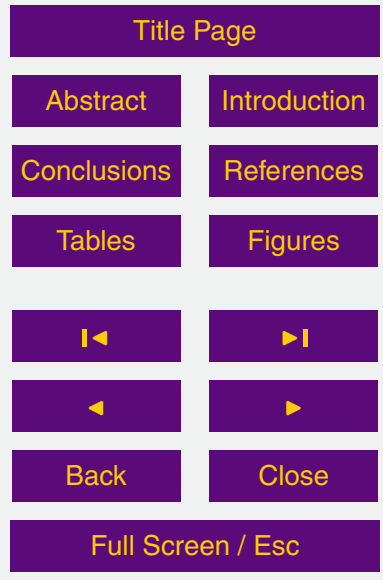

Printer-friendly Version

Interactive Discussion 
chemistry of sediment records (Meyers and Ishiwatari 1993; Meyers 1997, 2003). However, the interpretation of organic geochemical signals is not always straightforward because in most cases organic matter is a mixture of components from many sources and with variable degrees of preservation.

$5 \quad n$-Alkanes are among the biomarkers most commonly used. These compounds have the advantage that they are less susceptible to microbial degradation than other types of organic matter because they lack the functional groups that confer chemical reactivity, and also that they have low water solubility (Prahl and Carpenter, 1984; Meyers et al., 1995). The $n$-alkanes present in sediments reflect mainly the contribution from 10 algae, bacteria, aquatic macrophytes, and land plants. Several $n$-alkane ratios can be used for paleoenvironmental reconstruction purposes.

The logs of the various indexes related to the $n$-alkane content, namely the $n$-alkane predominant chain, the average chain length $(A C L)$, the aquatic macrophyte proxy (Paq), the Terrigenous/Aquatic Ratio of hydrocarbons $\left(\mathrm{TAR}_{\mathrm{HC}}\right)$, and the relative per15 centages of $\mathrm{C}_{27}, \mathrm{C}_{29}$ and $\mathrm{C}_{31}$ with respect to the sum $\mathrm{C}_{27}+\mathrm{C}_{29}+\mathrm{C}_{31}$, are shown in Fig. 3.

The SRA cores samples showed $n$-alkanes with an odd-over-even carbon number predominance, with a chain length distribution ranging mainly from $C_{17}$ to $C_{31}$. We detected an overwhelming domination of $C_{31} n$-alkane (44 over 54 samples), but in 10 of these samples the $\mathrm{C}_{21}$ homolog was predominant.

The ACL (Poynter, 1989), calculated as $\left[\left(\mathrm{C}_{i} \times i+\mathrm{C}_{i+1} \times(i+1)+\mathrm{C}_{i+2} \times(\mathrm{i}+2) \ldots+\right.\right.$ $\left.\left.\mathrm{C}_{n} \times n\right)\right) /\left(\sum \mathrm{C}_{i}+\mathrm{C}_{i+2}+\ldots+\mathrm{C}_{n}\right)$, with $i=13, n=33$ ], showed few oscillations (Fig. 3), with values varying between $21.9(15.9 \mathrm{~cm})$ and $28.0(640 \mathrm{~cm})$.

The Paq index, calculated as the $\left(\mathrm{C}_{23}+\mathrm{C}_{25}\right) /\left(\mathrm{C}_{23}+\mathrm{C}_{25}+\mathrm{C}_{29}+\mathrm{C}_{31}\right)$ ratio (Ficken 25 et al., 2000), allows discrimination between the relative contribution of aquatic macrophytes and terrestrial plants. Paq values registered several oscillations, but with a low range, falling between $0.05(150$ and $240 \mathrm{~cm})$ and $0.25(790 \mathrm{~cm})$.

\section{CPD}

11, 3897-3936, 2015

The MIS 5

palaeoenvironmental record in the SE

\section{Mediterranean coast}

T. Torres et al.

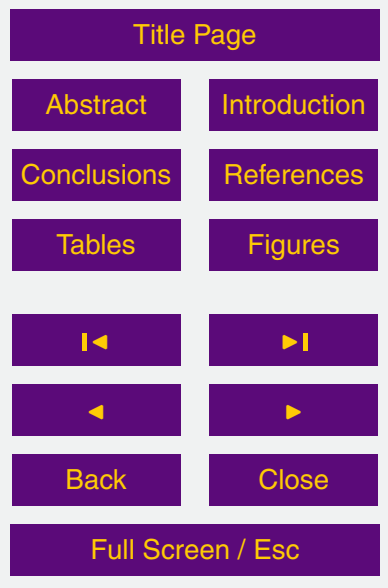

Printer-friendly Version

Interactive Discussion 
Silliman et al. (1996) reported that the terrigenous / aquatic ratio, calculated as $\left(\mathrm{C}_{31}+\right.$ $\left.\mathrm{C}_{29}+\mathrm{C}_{27}\right) /\left(\mathrm{C}_{15}+\mathrm{C}_{17}+\mathrm{C}_{19}\right)$, distinguishes between terrestrial plant and algal inputs. The TAR $_{\mathrm{HC}}$ index varied between $39.9(40 \mathrm{~cm})$ and $1.4(1660 \mathrm{~cm})$.

The $n$-alkane composition as relative percentages of $\mathrm{C}_{27}, \mathrm{C}_{29}$ and $\mathrm{C}_{31}$ with respect 5 to the sum $\mathrm{C}_{27}+\mathrm{C}_{29}+\mathrm{C}_{31}$ showed some oscillations (Fig. 3), but in all cases, the relative percentage of $\mathrm{C}_{31}$ accounted for more than $50 \%$ of the $n$-alkanes present, with a maximum at $760 \mathrm{~cm}(70 \%)$.

\subsection{Palynology}

Pollen was not present in the lowermost $(2850-1830 \mathrm{~cm})$ or uppermost $(280-0 \mathrm{~cm})$ part of the SRA record.

In the samples from the remaining record, we identified 39 taxa, of which 11 were trees (Pinus, Juniperus, Corylus, Betula, Juglans, Quercus deciduous, Olea, Quercus evergreen Alnus, Fraxinus and Ulmus), 6 bushes (Calluna, Ericaceae, Myrtus, Cistaceae, Pistacea, and Rosaceae), and 22 grasses (Asteraceae liguliflorae, Asteraceae tubuliflorae, Poaceae, Sanguisorba, Artemisia, Chenopodiaceae, Ephedra, Plantago, Polygonaceae, Rubiaceae, Rumex, Urtica, Apiaceae, Brassicaceae, Caryophyllaceae, Fabaceae, Boraginaceae, Scrophulariaceae, Asphodellus, Potentilla, Rhamnaceae and Violaceae). Also, we detected two aquatic species (Cyperaceae and Alisma). Monolete and trilete sporae and 15 non-pollinic microfossils (NPMs) from various affinities were also found: 3b type (Pleospora) of dry character, 55A (Sordaria) 113 (Sporomiella), 368 (Podospora) and Riccia of coprophilic affinity, as well as the mesoeutrophic types 181 and 731 and the eutrophic 170 type (Rivularia). We also detected deforestation-linked type 207 (Glomus cf. fasciolatum) and soil erosion-linked Pseudoeschizaeae circula.

25 The pollen assemblage reveals a Mediterranean climatic scenario with fluctuations of moisture and, in some intervals, mainly in the upper half of the section, the presence of Nitrophilous taxa.

\section{CPD}

11, 3897-3936, 2015

The MIS 5

palaeoenvironmental record in the SE Mediterranean coast

T. Torres et al.

\section{Title Page}

Abstract

Conclusions Introduction

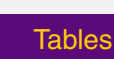

References

Tables Figures

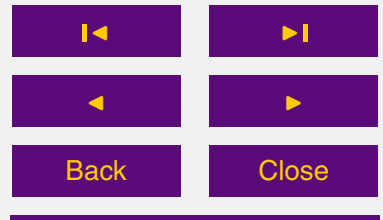

Full Screen / Esc

Printer-friendly Version

Interactive Discussion 
The pollen diagram (Fig. 4) reveals that tree cover was denser in the lower part of the record and more open at the top. Similarly, the shrubby stratum did not contribute greatly to the vegetation structure nor did NPM, aquatic taxa, or most of the elements identified in the trees or grasses groups.

$5 \quad$ Given the above observations, we built a synthetic diagram taking in consideration various taxa (Pinus, Juniperus) and associations of trees (Mesophilous, Mediterranean), grasses (Xeric, Steppic and Nitrophilous), NPM type 3b, and Coprophilous taxa (Fig. 5).

\section{Discussion}

\section{$10 \quad 5.1$ Sedimentary environments}

We differentiated the following five lithological units in the SRA borehole on the basis of sedimentological characteristics and microfossil content (Fig. 2): Unit I (29.7-28.2 m: Pliocene yellow-grey marls and silts; Unit II (28.2-24.2 m loosely cemented gravels interbedded with sands of Pleistocene age); Unit III (24.2-18.2.2 m loosely cemented 15 Pleistocene gravels and sands); Unit IV (18.2-3.0 m variegated lutites with bioclasts and gypsum); and Unit V (3.0-0.0 m laminated fine-grained sands). Because of some minor variations in lithology and biological content, Unit IV was sub-divided in ten (a-j) sub-episodes.

Although Pantaleón-Cano et al. (2003) identified these units in their borehole record, they observed peat deposits between 22.50 and ca. $20.60 \mathrm{~m}$ that were not present in the SRA core. Those authors did not provide the coordinates of their borehole, however, this discrepancy allows us to conclude that SRA and Pantaleón-Cano et al. (2003) boreholes were drilled in different areas of the paleo-lagoon.

Each sedimentary unit corresponded to a certain environment (Table 3, Fig. 2). With 25 the exception of marine conditions that occurred during the Pliocene, the basin showed evidence of alluvial fan progradation alternating with lagoonal and palustrine episodes.

\section{CPD}

11, 3897-3936, 2015

The MIS 5

palaeoenvironmental record in the SE Mediterranean coast

T. Torres et al.

\section{Title Page}

Abstract

Conclusions

Tables Figures

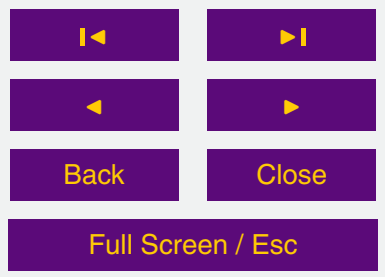

Printer-friendly Version

Interactive Discussion 
The alternation of these cycles was especially common during MIS6 and 5, reflecting environmental changes that do not necessarily coincide with climate changes inferred from the palynological interpretation. These deviances can be explained by offset between climate and sedimentological response.

Thus, the Pleistocene record of the SRA borehole was deposited during two periods (Table 3, Fig. 2): the lowermost sands belonging to Units II and III corresponded to MIS11, whereas the lutites of Unit IV (uppermost $16 \mathrm{~m}$ ) belonged to the end of MIS6 and MIS5, the latter fully recorded. The stratigraphical hiatus corresponding to the MIS11-MIS6 period explains the distinct geomechanical characteristics of the two 10 deposits (cemented and compacted vs. uncemented and water-soaked). These units can be correlated with beach and bar deposits of the same age.

During MIS11 alluvial fan conditions were predominant in the Vera Basin. Thick massive gravels in the lower half of the record, followed by silts with short palustrine episodes (autochthonous ostracods) can be identified as fan toe sediments. We were 15 unable to determine othe paleoenvironmental conditions because of the lack of pollen grains.

No marine record from MIS6 was found on land, but marine geology mapping (Díaz del Río and Fernández Salas, 2005) of the area revealed a long, wide strip of coarse sand at a depth of $60-70 \mathrm{~m}$, which may represent an undated lowstand system track 20 LST (MIS6?).

We consider the AAR ages obtained for the MIS6 deposits feasible. The lower half of the record identified the margin of a playa lake which, in the upper half, changed to the red-brown silty sediments of a mud flat. According to the pollen record, the playa lake deposits correspond to dry-cold (relatively) conditions followed by humid 25 and temperate-warm ones. During the deposition of the mud flat, cool and dry conditions dominated. Although MIS6 showed markedly unfavorable climatic conditions, as in other areas of southern Iberia, this period was a "climatic amelioration" when compared with MIS5.

\section{CPD}

11, 3897-3936, 2015

The MIS 5

palaeoenvironmental record in the SE

\section{Mediterranean coast}

T. Torres et al.

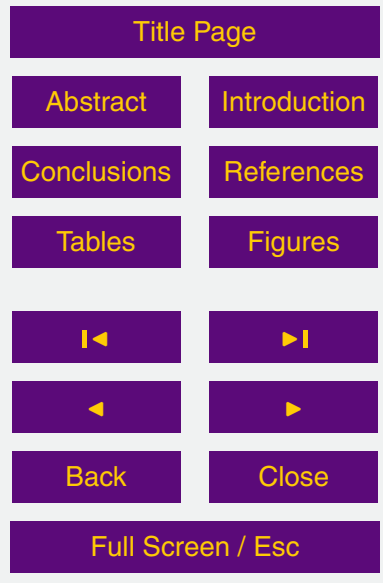

Printer-friendly Version

Interactive Discussion 


\subsection{Organic geochemistry (biomarkers)}

A short description of the $n$-alkane indices used is given in Table 4. $n$-Alkane content provided reliable information on the local distribution of plants, thus completing the more regional data provided by pollen analysis.

The predominance of the $\mathrm{C}_{31} n$-alkane in most of the samples indicated the main input of grasses along the whole record (Fig. 3). Levels maximizing in the $C_{21}$ homolog can be linked to aquatic macrophyte dominance, usually associated with the presence of aquatic fauna remains (ostracods and/or pelecypoda), as occurred in subunits IV-a (1690), IV-c (1390, 1360), IV-e $(820,790)$ and IV-i $(550,520)$. However, Unit

10 II (2840), Unit III (2050) and sub-unit IV-b did not hold faunal remains (Fig. 2). In all cases ephemeral shallow water masses appear to have developed.

The variations in Average Chain Length (ACL) values were small, although some clarifications can be made. In this regard, the ACL values oscillated between 21.9 and 28.0, implying a reduced contribution of low molecular weight $n$-alkanes, usually linked

15 to algae and bacteria. However, the ACL values were slightly lower in Units II, III and subunits IV-a and IV-b, indicating a growth of aquatic taxa.

The dominance of organic matter derived from terrestrial plants over algae input can also be interpreted from the $\mathrm{TAR}_{\mathrm{HC}}$ index, which showed values higher than 1.5 in all cases, being higher than 3.0 in $80 \%$ of the samples.

The Paq values were originally defined and used to determine the relative contribution of macrophyte taxa and terrestrial plants to some African lakes (Ficken et al., 2000). According to Ficken et al. (2000), Paq values under 0.1 are linked to a dominant contribution from land plants, while values between 0.1 and 0.4 reflect significant inputs from emergent macrophytes. Paq values higher than 0.4 are typical in sediments with 25 a major $n$-alkane input of submerged/floating macrophytes. In the SRA record, most of the samples showed Paq values between 0.05 and 0.25 , indicating a major input of terrestrial plants and emergent macrophytes. The absence of submerged macrophyte dominance indicates that the water mass was limited in time and depth.

\section{CPD}

11, 3897-3936, 2015

The MIS 5

palaeoenvironmental record in the SE Mediterranean coast

T. Torres et al.

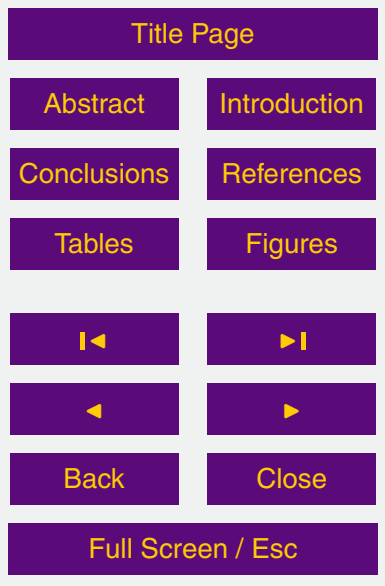

Printer-friendly Version

Interactive Discussion 
In agreement with the lowest ACL values observed in the lower half of the record (Units II, III and sub-units IV a-b), Paq values were between 0.1 and 0.26 , suggesting a considerable contribution of emerging macrophytes. In contrast, in the upper half of the record, most of the samples showed Paq values lower than 0.1 , linked to terrestrial 5 plants, with the exception of five excursions to higher values linked to a major input from emerging macrophytes (samples from 970, 910, 790, 520 and $300 \mathrm{~cm}$ ). Episode $V$ showed a greater terrestrial input, which can be explained by its alluvial character, with floating terrestrial plant debris still visible at the incised river banks.

The relative percentage of $\mathrm{C}_{31}$ with respect to the sum $\mathrm{C}_{27}+\mathrm{C}_{29}+\mathrm{C}_{31}$ showed cer10 tain oscillations, thus allowing us to discriminate the origin of $n$-alkane from terrestrial sources. A percentage greater than $50 \%$ reflects grass-origin predominance. However, we established three subtle zoning:

- Although the record showed grass dominance, three dominions were clearly differentiated: Episode II to Episode IV-b $(2840-1360 \mathrm{~cm})$ showed a saw-tooth dis-

\subsection{Palynology}

Analysis of the evolution of the pollen frequencies allowed us to distinguish seven (IVII) climate-related phases in the synthetic diagram (Fig. 5). Unfortunately, due to a lack of pollen grains in sediments belonging to MIS11, paleoenvironmental conditions

\section{CPD}

11, 3897-3936, 2015

The MIS 5

palaeoenvironmental record in the SE

\section{Mediterranean coast}

T. Torres et al.

\section{Title Page}

Abstract Introduction

Conclusions References

Tables

Figures

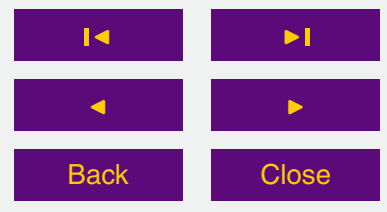

Full Screen / Esc

Printer-friendly Version

Interactive Discussion 
In Phase I (1850-1700 cm), the pollen content was low, although Pinus and Poaceae were present. Towards the top, the presence of Mediterranean, Xeric, and Nitrophilous taxa increased and then decreased dramatically at the end of this phase, favoring the presence of Juniperus. We interpret these observations as an initial warm and dry 5 climate, turning to a cold one, as attested by the development of Juniperus.

Phase II $(1700-1550 \mathrm{~cm})$ began with a sharp decrease in the presence of Juniperus, which favored the growth of Mesophilous taxa and later Mediterranean species, the frequencies of Xeric and Steppic taxa being low. Nitrophilous taxa increased and scattered samples of Aquatic taxa appeared. We interpret these climatic conditions as 10 temperate-warm and humid.

In Phase III (1550-1330 cm), there was a clear dominance of Pinus, followed by Xeric and Steppic taxa and, to a lesser extent, Nitrophilous and NPM-3B taxa. We interpret these data as indicative of a dry and colder period, as attested by the low development of Mesophilous and Mediterranean taxa.

15 In Phase IV (1330-1120 cm), there was a clear expansion of Mediterranean taxa, with some oscillations, together with an increasing presence of Xeric and Steppic taxa, as well as Juniperus towards the top, marking a temperature increase under dry conditions.

In Phase V (1130-840 cm), Mediterranean and Mesophilous taxa clearly dominated, 20 though with some oscillations. There was a clear decline in the presence of Pinus, and Juniperus disappeared. At the beginning of this phase the presence of Aquatic and Nitrophilous taxa increased and in the upper part they were replaced by Xeric taxa and NPM-3b, ending with a short period in which the pollen content was practically absent. We interpret these observations as indicating a warm period that was initially relatively humid and that evolved towards dry conditions; this phase can be correlated with MIS5e.

Phase VI $(840-700 \mathrm{~cm})$ started with an increase in Juniperus and Steppic taxa, which were later substituted by Mediterranean and Mesophilous ones. The presence

\section{CPD}

11, 3897-3936, 2015

The MIS 5

palaeoenvironmental record in the SE

\section{Mediterranean coast}

T. Torres et al.

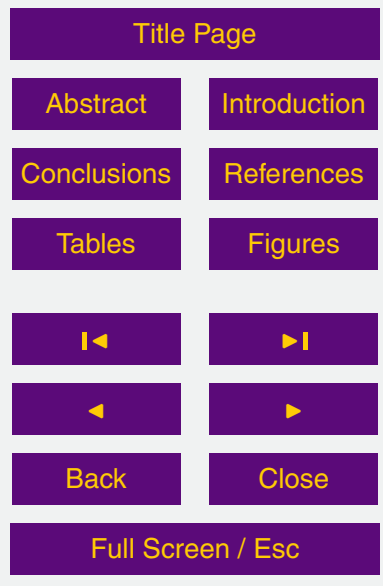

Printer-friendly Version

Interactive Discussion 
of Aquatic and Nitrophilous taxa showed a clear increase. These data indicate that temperate and humid conditions dominated during this phase.

In Phase VII $(700-290 \mathrm{~cm})$, the presence of Pinus and Juniperus fluctuated and alternated, and both genera tended to diminish towards the top of the record. There was 5 a significant increase in Steppic and Xeric taxa. In spite of this general trend, Mediterranean taxa showed a progressive growth accompanied by a slight development of Mesophilous ones. These data reflect warm and dry conditions, with some periods with extremely water shortage.

To interpret the pollen assemblages, we performed a principal components anal10 ysis (Fig. 6) on the data used for the synthetic diagram. Component 2 (explaining $56.55 \%$ of the variability) grouped samples on the basis of the development of the local Mesophilous and Mediterranean taxa (positive values) versus open landscapes and regional Pinus forest (negative values). In contrast, Component 3 (explaining $72.15 \%$ of the variability) clustered taxa marking warmer conditions (positive values) and those 15 indicating temperate or cool conditions (negative values).

According to these results, cold-to-temperate and humid conditions developed during MIS6, coinciding with the paleoclimatological interpretation of the Fuentillejo core (Ruiz Zapata et al., 2012), located $300 \mathrm{~km}$ north-west of the SRA borehole in the same climatic zone (Fig. 1), as well as with the growth of tufa deposits in the Iberian Peninsula 20 (Torres et al., 2005; Ortiz et al., 2009). In contrast, warm and arid conditions occurred at the end of MIS6 (140-133 ka) both in the Fuentillejo (Ruiz Zapata et al., 2012) and SRA cores.

At the beginning of MIS5 climatic conditions were warmer but less dry, with the recovery of the Mediterranean forest, Mesophilous taxa and Pinus in Phase 5, which corresponds to MIS5e, and coinciding with pollen data of the Fuentillejo core (Ruiz Zapata et al., 2012). Fuentillejo maar lake developed under a continental-mediterranean climate.

During the rest of MIS5, the alternation of Juniperus, Xeric and Mesomediterranean taxa indicate short cold-dry episodes within this interglaciar period.

\section{CPD}

11, 3897-3936, 2015

The MIS 5

palaeoenvironmental record in the SE

\section{Mediterranean coast}

T. Torres et al.

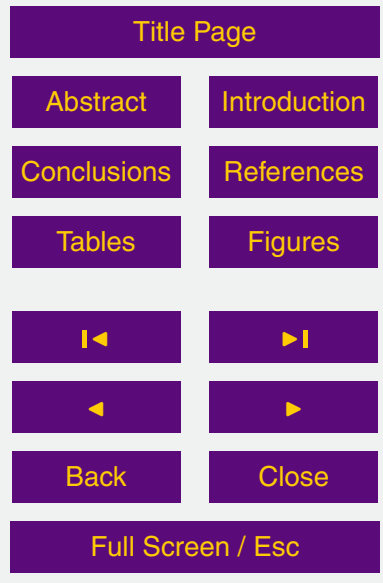

Printer-friendly Version

Interactive Discussion 
Thus the palynological data revealed that paleoenvironmental fluctuations were not as extreme as in other areas of the Mediterranean realm and Central Europe.

\section{Conclusions}

The abundance of the ostracod $C$. torosa in almost all the beds of the SRA core allowed 5 AAR dating of the Middle-Upper Pleistocene record of the Vera Basin in the vicinity of Garrucha village (between the mouths of the rivers Antas and Aguas), with a sedimentary hiatus between MIS11 and MIS6 and 5 deposits. It is noticeable that MIS5 was extensively represented in the SRA core, covering almost $11.5 \mathrm{~m}(14.5-3.0 \mathrm{~m})$. The accuracy of AAR has been tested through the coincidence of $U / T h$ and AAR ages of 10 the neighbor zone of Alfaix.

It was proved a clear relationship between the P. latus bearing MIS5 bar along the Garrucha coastline and the fine grained lagoon record of the same age that allowed the paleoenvironmental reconstruction. In fact, MIS5 coastal bars played a decisive role in the present-day coastline morphology allowing the permanence of fossil or stillactive lagoons. There are other examples along the Spanish Mediterranean coast of active lagoons where the active bar results to be anchored on fossil bars (MIS5): Calblanque (Lillo, 1988) and Mar Menor in Murcia (Lillo, 1988; Colodrón et al., 1977), Elche (Blázquez, 2005), La Mata (Somoza et al., 1986; Zazo et al., 1993; Santisteban et al., 2004), and Pego (Torres et al., 2013) in Alicante. In any case it seems that a rich paleo-environmental record seems to be waiting for future research.

On the basis of the lithology and sedimentological characteristics, we distinguished six associations of lithofacies, corresponding to lagoon deposits and distal alluvial fan influence.

Organic geochemistry, namely $n$-alkane content, which is extensively used in pa25

\section{CPD}

11, 3897-3936, 2015

The MIS 5

palaeoenvironmental record in the SE Mediterranean coast

T. Torres et al.

\section{Title Page}

Abstract

Conclusions Introduction References

Tables Figures

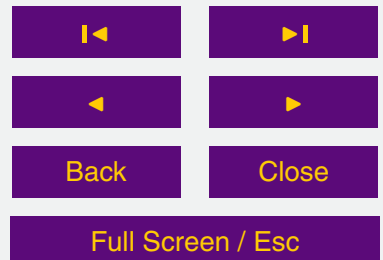

Printer-friendly Version

Interactive Discussion 
trial plant-derived biomarkers to a shallow wetland, where emergent macrophytes were also present in varying amounts.

Sedimentation during MIS11 was partially represented by alluvial fan sediments (Unit II) that retracted towards its end (Unit III). Unfortunately, we were unable to interpret 5 the paleoclimatic conditions because the record was devoid of pollen content.

The end of MIS6 was confidently dated and represented by playa-lake marginal deposits (subunit IV-a). Towards the end of MIS6, the alluvial system was reactivated, as reflected in fine gravel and sand deposition (subunit VI-b). Frequent root tubuli indicate aerial exposure. The pollen content analysis revealed that this stage showed 10 milder climatic conditions (warm-temperate) than the beginning of MIS5e (cool), although varying from dry to humid.

MIS5 was confidently dated and presumably all the sub-stages were represented, although AAR ages showed some uncertainties. During MIS5 a series of three lagoonalluvial couplets were identified through sedimentological characteristics and the micropaleontological content. The lagoonal episodes were marked by the presence of autochthonous foraminifers and brackish-water mollusks and ostracods, the presence of which indicates larger marine ingressions during the MIS5e substage. Although these marine conditions never prevailed, as the lower presence of algae biomarkers suggest, the environment was characterized by intermittent sea-water entrance and emergent macrophyte colonization but with dominant periods of dryness in which interstitial gypsum lenses developed, the dried surface of which was grass-colonized, as attested by biomarker analysis.

Alternation of episodes of lagoonal and alluvial fan progradation were also observed in the Pleistocene record of the nearby Elche and Pego basins (Fig. 1; cf. Blázquez, 2005; Blázquez and Usera, 2010; Torres et al., 2013).

Our analysis of pollen content revealed that nuanced Mediterranean biomes were ever-present, showing a small degree of decoupling with sedimentary environments.

- MIS5e is well represented by lagoonal sediments with ostracods, foraminifera and brackish water pelecipoda (subunits IV c-e). According to the pollen record, cli-

\section{CPD}

11, 3897-3936, 2015

The MIS 5

palaeoenvironmental record in the SE Mediterranean coast

T. Torres et al.

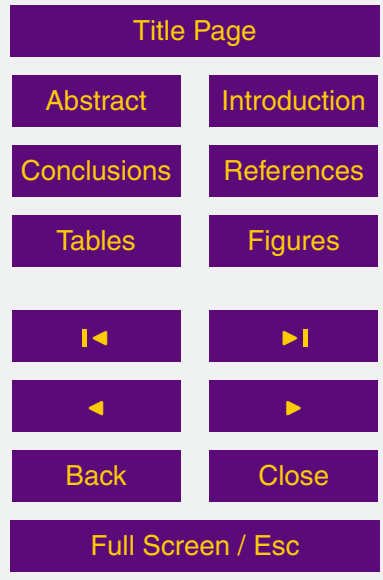

Printer-friendly Version

Interactive Discussion 
mate conditions changed from warm-dry to warm and more humid, ending with more temperate conditions.

- MIS5d can be correlated with the sedimentary subunit IV-f, marking some progradation of the alluvial systems, and temperate and humid conditions.

- MIS5c correlates with subunit IV-g in which lagoonal conditions prevailed. According to the pollen record, warm and dry conditions prevailed.

- MIS5b corresponds to subunit IV-h, which marks a new alluvial progradation with azoic sediments, although the pollen record indicated warm and dry climatic conditions.

- MIS5a (subunits IV-i and IV-j) began with the re-establishment of lagoonal conditions (ostracods, brackish water pelecipoda, Helicidae) under warm and dry conditions, although the end of this period was marked by alluvial fan progradation.

The paleogeographical reconstruction suggests that the present-day Antas river channel incised an ancient lagoon at the end of Upper Pleistocene after a sudden shift southwards.

Acknowledgements. Funding was obtained through the projects "Paleoclimatological revision of climate evolution in Western Mediterranean region" (European Union, CE-FI2W-CT91-0075) and "Paleohidrogeological Data Analysis and Model Testing" (European Union, FIKW-CT-200100129). The Biomolecular Stratigraphy Laboratory has been partially funded by ENRESA.

\section{References}

Badal, E. and Roiron, P.: La prehistoria de la vegetación en la Península Ibérica, Saguntum 28, 29-48, 1995.

Blázquez, A. M.: Evolución cuaternaria de l'Albufera d'Elx: Paleoambientes y foraminíferos fósiles. Memorias del Museo Paleontológico de Elche, Universidad de Alicante and MUPE

\section{CPD}

11, 3897-3936, 2015

The MIS 5

palaeoenvironmental record in the SE

\section{Mediterranean coast}

T. Torres et al.

\section{Title Page}

Abstract Introduction

Conclusions References

Tables

Figures

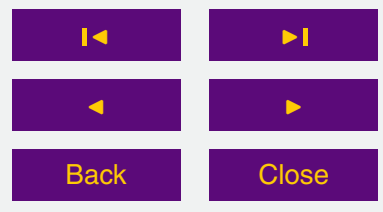

Full Screen / Esc

Printer-friendly Version

Interactive Discussion 
Blázquez, A. M., and Rodríguez Pérez, A.: Micropaleontología y cambios ambientales en la marjal de Almenara (Castellón) durante los últimos milenios, in: El Cuaternario Ibérico: investigación en el siglo XXI, edited by: Baena, R., Fernández, J., and Guerrero, I., GTPEQAEQUA Universidad de Sevilla, Sevilla, 103-107, 2013.

5 Blázquez, A. M. and Usera, J.: Palaeoenvironments and Quaternary foraminifera in the coastal lagoon of Elx (Alicante, Spain), Quatern. Int., 221, 68-90, 2010.

Blumer, M., Guillard, R. R. L., and Chase, T.: Hydrocarbons of marine plankton, Mar. Biol., 8, 183-189, 1971.

Brown, T. A., Nelson, D. E., Mathees, R. W., Vogel, J. S., and Southon, J. R.: Radicarbon dating of pollen by mass spectrometry, Quaternary Res., 32, 205-212, 1989.

Burjachs, F. and Juliá, R.: Abrupt climatic changes during the last glaciation based on pollen analysis of the Abric Romani, Catalonia, Spain, Quaternary Res., 42, 308-315, 1994.

Carrión, J. S. and Dupré, M.: Late Quaternary vegetational history at Navarrés, eastern Spain, A two core approach, New Phytol., 134, 177-199, 1996.

Carrión, J. S. and van Geel, B.: Fine-resolution Upper Weichselian and Holocene palynological record from Navarrés (Valencia, Spain) and a discussion about factors of Mediterranean forest succession, Rev. Palaeobot. Palyno., 106, 209-236, 1999.

Carrión, J. S., Munuera, M., Navarro, C., Burjachs, F., Dupré, M., and Walker, M. J.: The palaeoecological potential of pollen records in caves: the case of Mediterranean Spain, Quaternary Sci. Rev., 18, 1061-1073, 1999.

Causse, Ch., Goy, J. L., Zazo, C., and Hillaire-Marcel, C. : Potential chronologique (Th/U) des faunes Pléistocenes Mediterranéennes: example des terrasses marines des regions de Murcie et Alicante (South-Est de l'Espagne), Geodin. Acta, 6, 121-134, 1993.

Collado, M. A. and Robles, F.: Estudio de las asociaciones de moluscos de la turbera holocena de Torreblanca (Castellón), Mediterránea Serie Geológica, 1, 105-142, 1983.

Colodrón, I., Núñez, A., and Martínez, W.: Mapa Geológico de España 1:50.000, hoja no 956 (San Javier), IGME, Madrid, 13 pp., 1977.

Cranwell, P. A.: Lipid geochemistry of sediments from Upton Broad, a small productive lake, Org. Geochem., 7, 25-37, 1984.

30 Cranwell, P. A., Eglinton, G., and Robinson, N.: Lipids of aquatic organisms as potential contributors to lacustrine sediments-II, Org. Geochem., 11, 513-527, 1987.

Díaz del Río Español, V., and Fernández Salas, L. M.: El margen continental del levante español y las Islas Baleares in Martín Serrano A, Mapa Geomorfológico de España y del
CPD

11, 3897-3936, 2015

\section{The MIS 5 \\ palaeoenvironmental record in the SE \\ Mediterranean coast}

T. Torres et al.

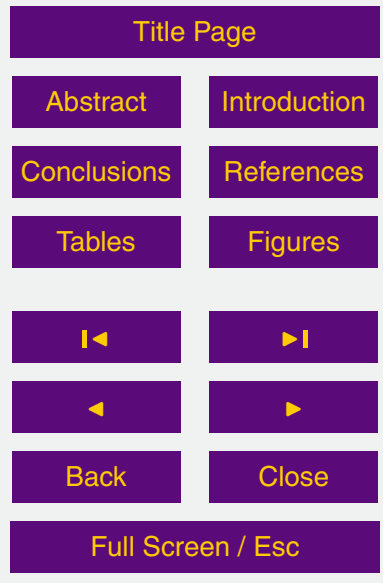

Printer-friendly Version

Interactive Discussion 
margen continental a escala 1:1.000.000,Instituto Geológico y Minero de España, 177-188, 2005.

Dupré, M., Fumanal, M. P., Sanjaume, E., Santisteban, C., Usera, J., and Viñals, M. J.: Queternary evoltion of the Pego coastal lagoon (Southern Valencia, Spain), Palaeogeogr. Palaeoecol., 68, 291-299, 1988.

Ferré Bueno, E.: El Valle del Almanzora: estudio geográfico, Exma, Diputación Provincial, Almería, 494 pp., 1979.

Ferrer, C. and Blázquez, A.M.: The evolution of the Albufereta Lagoon (western Mediterranean): Climate Cycles and Sea Level Changes, J. Coast. Res., 28, 1617-1626, 2012.

10 Ferrer, C., Blázquez, A. M., Esquembre, M. A., and Ortega, J. R.: Reconstrucción paleoambiental de l'Albufereta d'Alacant durante el período ibero-romano (500 a.C.-300 d.C.), in: Geomorfologia litoral i Quaternari, edited by: Sanjaume, E. and Mateu, J. F., Homenatge al professor Vicenç M. Rosselló i Verger, Universidad de Valencia, Valencia, 137-150, 2005.

Ficken K. J., Li, B., Swain, D. L., and Eglinton G.: An $n$-alkane proxy for the sedimentary input 15

Fumanal, M. P. and Dupré, M.: Aportaciones de la sedimentología y de la palinología al conocimiento del paleoambiente valenciano durante el Holoceno, in: Quaternary climate in western Mediterranean, edited by: López Vera, F., Universidad Autónoma de Madrid, Madrid, 325-343, 1986.

20 Fumanal, M. P., Usera, J., Viñals, M. J., Mateu, G., Belluomini, G., and Proszynska-Bordas, H.: Evolución cuaternaria de la bahía de Xàbia (Alicante), in: Estudios sobre Cuaternario, edited by: Fumanal, P. and Bernabeu, J., Medios Sedimentarios, cambios Ambientales, Habitat Humano, Universidad de Valencia, Valencia, 17-27, 1993.

Gelpi, E., Schneidera, H., Manna, J., and Oróa, J.: Hydrocarbons of geochemical significance in microscopic algae, Phytochemistry, 9, 603-612, 1970.

Goy, J. L., Zazo, C., and Hillaire-Marcel, C. : Stratigraphie et chronologie (U/Th) du Thyrrénien du Sud-Est de l'Espagne, Z. Geomorphol., 62, 71-82, 1986.

Hearty, P. J.: An Inventory of Last Interglacial (sensu lato) Age Deposits from the Mediterranean Basin, Z. Geomorphol., 62, 51-69, 1986.

30 Hearty, P. J.: New data on the Pleistocene of Mallorca, Quaternary Sci. Rev. 6, 245-257, 1987. Hearty, P. J., Miller, G., Stearns, C., and Szabo, B. J.: Aminostratigraphy of Quaternary shorelines in the Mediterranean basin, Geol. Soc. Am. B., 97, 850-858, 1986.

\section{CPD}

11, 3897-3936, 2015

\section{The MIS 5 \\ palaeoenvironmental record in the SE \\ Mediterranean coast}

T. Torres et al.

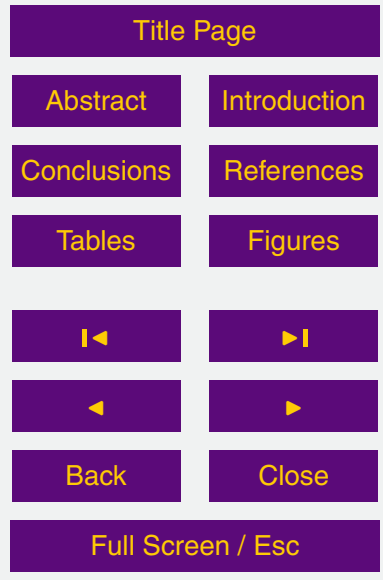

Printer-friendly Version

Interactive Discussion 
Hernández Ruiz, M., Del Val, J., and Viñals, M. J.: Aplicación de técnicas geofísicas al estudio del Cuaternario: prospección geoeléctrica mediante S.E.V. en el Marjal de Oliva-Pego (Valencia-Alicante), Cuaternario y Geomorfología, 7, 79-90, 1993.

Hillaire-Marcel, C., Carro, O., Causse, Ch., Goy, J. L., and Zazo, C.: Th/U dating of Strombus bubonius bearing marine terraces in southeastern Spain, Geology, 14, 613-616, 1986.

Kaufman, D. S.: Amino acid racemization in ostracodes, edited by: Goodfriend, G. A., Collins, M. J., Fogel, M. L., Macko, S. A., and Wehmiller, J. F., in: Perspectives in Amino Acids and Protein Geochemistry, Oxford University Press, New York, 145-160, 2000.

Kaufman, D. S. and Manley, W. F.: A new procedure for determining DL amino acid ratios in fossils using reverse phase liquid chromatography, Quat. Geochronol., 17, 987-1000, 1998.

Lillo, M.: Consideraciones sobre los afloramientos tirrenienses detectados entre Cabo Roig (Alicante) y la desembocadura del rio Almanzora (Almería), Cuadernos de Geografía, 14, 51-81, 1988.

Lowe J. J., Lowe S., Fowler A. J., Hedges, R. E. M., and Austin, T. J. F.: Comparison of ac15 celerator and radiometric and radiocarbon measurements obtained from late Devensian late glacial lake sediments from Llyn Gwernan, North Wales U.K. Boreas, 17, 355-369, 1988.

MacDonald, G. M., Beukens, R. P., Kieser, W. E., and Vitt, D. H.: Comparative radiocarbon dting of terrestrial plant macrofossil and aquatic moss from the "ice.free" corridor of western Canada, Geology 15, 837-840, 1987.

20 Mateu, G.: Sondeo de l'Albufera de Pego: Micropaleontología y biofacies, Cuadernos de Geografía, 49, 1-9, 1989.

Mateu, G., Viñals, M. J., and Moreiro, M.: Biofacies marginolitorales del Mediterráneo Occidental (Baleares, Valencia, Alicante y Murcia), Boletín de la Sociedad de Historia Natural de Baleares, 40, 123-134, 1997.

Ogura, K., Machilara, T., and Takada, H.: Diagenesis of biomarkers in Biwa lake sediments over 1 million years, Org. Geochem., 16, 805-813, 1990.

Olsson, I. U.: A study of errors in ${ }^{14} \mathrm{C}$ dates of peat and sediment, Radiocarbon, 28, 429-435, 1986.

Ortiz, J. E., Torres, T., Julià, R., and Llamas, F. J.: Algoritmos de cálculo de edad a partir de relaciones de racemización/epimerización de aminoácidos en pelecípodos marinos del litoral mediterráneo español, Revista de la Sociedad Geológica de España, 17, 217-227, 2004a.

Ortiz, J. E., Torres, T., Delgado, A., Julià, R., Llamas, F. J., Soler, V., and Delgado, J.: Numerical dating algorithms of amino acid racemization ratios analyzed in continental ostracodes of the

\section{CPD}

11, 3897-3936, 2015

\section{The MIS 5 \\ palaeoenvironmental record in the SE \\ Mediterranean coast}

T. Torres et al.

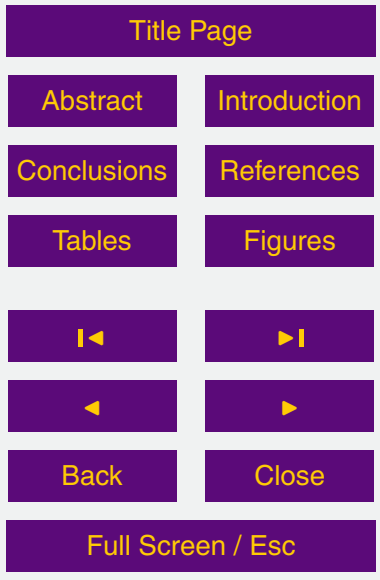

Printer-friendly Version

Interactive Discussion 
Iberian Peninsula (Spain). Application to Guadix-Baza Basin (southern Spain), Quaternary Sci. Rev., 23, 717-730, 2004b.

Ortiz, J. E., Torres, T., Delgado, A., Reyes, E., and Díaz-Bautista, A.: A review of the Tagus river tufa deposits (central Spain): age and palaeoenvironmental record, Quaternary Sci. Rev., 28, 947-963, 2009.

Ortiz, J. E., Torres, T., and Pérez-González, A.: Amino acid racemization in four species of ostracodes: Taxonomic, environmental, and microstructural controls, Quat. Geochronol., 16, 129-143, 2013.

Pantaleón-Cano J., YII E. I., Pérez-Obiol, R., and Roure, J. M.: Palynological evidence for vegetational history in semi-arid areas of the western Mediterranean (Almería, Spain), Holocene, 13, 109-119, 2003.

Pérez-Obiol, R. and Julia, R.: Climatic change on the Iberian Peninsula recorded in a $30000-y r$ pollen record from Lake Banyoles., Quaternary Res., 41, 91-98, 1984.

Ruiz-Zapata, B., Vegas, J., Gil-García, M. J., Gallardo-Millán, J.L., Galan, L., Ortiz, J. E., 15 Moreno, L., García-Cortés, A., and Torres, T.: Registro polínico durante el SaalienseEemiense en la secuencia lacustre del maar de Fuentillejo (Ciudad Real), Geo-Temas, 13, 245-249, 2012.

Santisteban, J. I., Mediavilla, R., Martínez, P., Castaño, S., Martínez, P. E., Murillo, J. M., López-Geta, J. A., and Rodríguez-Hernández, L.: Nuevos datos sobre la estratigrafía del subsuelo del acuífero de Torrevieja (Alicante): implicaciones en el modelo conceptual de funcionamiento, VIII Simposio de hidrogeología, Hidrogeología y recursos hidraulicos XXVIII, 215-233, 2004.

Segura, F., Pardo, J., and Sanjaume, E.: Evolución cuaternaria de la albufera de Torreblanca, Cuaternario y Geomorfología, 11, 3-18, 1997.

Schulte, L., Julià, R., Burjachs, F., and Hilgers, A.: Middle Pleistocene to Holocene geochronology of the River Aguas terrace sequence (Iberian Peninsula): Fluvial response to Mediterranean environment change, Geomorphology, 98, 13-33, 2008.

Schwark, L., Zink, K., and Lechtenbeck, J.: Reconstruction of postglacial to early Holocene vegetation history in terrestrial Central Europe via cuticular lipid biomarkers and pollen records from lake sediments, Geology, 30, 463-466, 2002.

Silliman, J. E., Meyers, P. A., and Bourbonniere, R. A.: Record of postglacial organic matter delivery and burial in sediment of Lake Ontario, Org. Geochem., 24, 463-472, 1996.

\section{CPD}

11, 3897-3936, 2015

\section{The MIS 5 \\ palaeoenvironmental record in the SE \\ Mediterranean coast}

T. Torres et al.

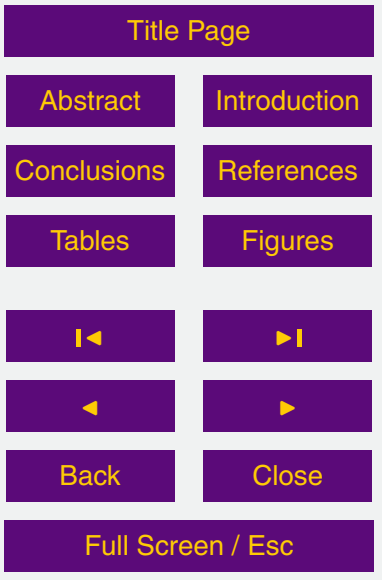

Printer-friendly Version

Interactive Discussion 
Somoza, L., Bardají, T., Dabrio, C. J., Goy, J. L., and Zazo, C.: Análisis de secuencias de islas barrera pleistocenas en relación con variaciones del nivel del mar, laguna de La Mata (Alicante), Acta Geológica Hispánica, 21-22, 151-157, 1987.

Stokes, M.: Plio-Pleistocene drainage development in an inverted sedimentary basin: Vera basin, Betic Cordillera, SE Spain, Geomorphology, 100, 193-211, 2008.

Torres, T., Llamas, J. F., Canoira, L., Coello, J., García-Alonso, P., and Ortiz, J. E.: Aminostratigraphy of two marine sequences from the Mediterranean coast of Spain, Cabo de Huertas (Alicante) and Garrucha (Almería), in: Perspectives in Amino Acid and Protein Geochemistry, edited by: Goodfriend, G. A., Collins, M. J., Fogel, M. L., Macko, S. A., and Wemiller J.

10 F., Oxford University Press, New York, 263-278, 2000a.

Torres, T., Soler, V., Ortiz, J. E., Llamas, J. F., Canoira, L., García de la Morena, M. A., and Civis, J.: Nuevas acotaciones del método de datación por análisis de racemización de aminoácidos: la serie de Cuesta Colorada (Almería), Geogaceta, 28, 137-140, 2000b.

Torres, T., Ortiz, J. E., García de la Morena, M. A., Llamas, F. J., and Goodfriend, G.: Aminos15 tratigraphy and aminochronology of a tufa system in Central Spain, Quatern. Int., 135, 21-33, 2005.

Torres T., Ortiz, J. E., Puche, O., De la Vega, R., and Arribas, A.: Biometría de Strombus bubonius Lamark 1791 del yacimiento de Cerro Largo (Roquetas de Mar, Almería), Geogaceta, 40, 167-170, 2006.

20 Torres, T., Ortiz, J. E., Arribas, I., Delgado, A., Julià, R., and Martín-Rubí, J. A.: Geochemistry of Persistrombus latus Gmelin from the Pleistocene Iberian realm, Lethaia, 43, 143-163, 2010a.

Torres, T., Ortiz, J.E., Grün, R., Eggins, S., Valladas, H., Mercier, N., Tisnèrat-Laborde, N., Julià, R., Soler, V., Martínez, E., Sánchez-Moral, S., Cañaveras, J. C., Lario, J., LaluezaFox, C., Badal, E., Rosas, A., Santamaría, D., de la Rasilla, M., and Fortea, J.: Dating of the hominid (Homo neanderthalensis) remains accumulation from El Sidrón cave (Piloña, Asturias, North Spain): an example of multi-methodological approach to the dating of Upper Pleistocene sites, Archaeometry, 52, 680-705, 2010b.

Torres, T., Ortiz, J.E., Martín-Sánchez, D., Arribas, I., Moreno, L., Ballesteros, B., Blázquez, A., 30 Domínguez, J. A., and Rodríguez Estrella, T.: The long Pleistocene record from the PegoOliva marshland (Alicante-Valencia, Spain), in: Sedimentary Coastal Zones from High to Low Latitudes: Similarities and Differences, edited by: Martini, I. P. and Wanless, H. R., Geological Society, London, Special Publications, 388, 1-24, 2013.

\section{CPD}

11, 3897-3936, 2015

\section{The MIS 5 \\ palaeoenvironmental record in the SE Mediterranean coast}

T. Torres et al.

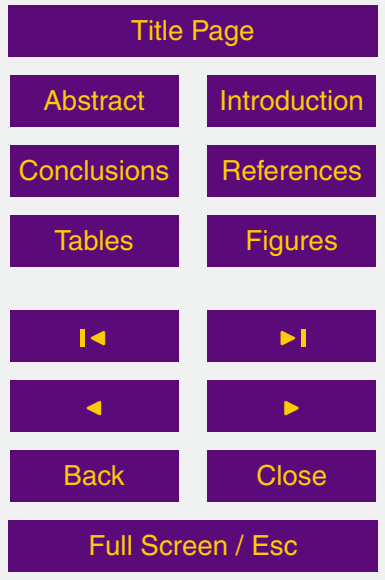

Printer-friendly Version

Interactive Discussion 
Usera, J., Blázquez, A .M., Guillem, J., and Alberola, C.: Biochronological and paleoenvironmental interest of foraminifera lived in restricted environments: application to the study of the western Mediterranean Holocene, Quatern. Int., 93-94, 139-147, 2002.

Usera, J., Blázquez, A. M., Guillem, J., and Alberola, C.: Evolución holocena de la Marjal de Peñíscola (Castellón, España) deducida del estudio de sus foraminíferos fósiles, Revista Española de Micropaleontología, 38, 381-393, 2006.

Viñals, M. J.: Secuencias estratigráficas y evolución morfológica del extremo meridional del Golfo de Valencia (Cullera-Dénia), in: El Cuaternario del País Valenciano, edited by: Grup Valencià Quaternari, University of Valencia, Valencia, 163-167, 1995a.

10 Viñals, M. J.: Formaciones litorales fósiles en la costa de Moraira (Alicante), En El Cuaternario del País Valenciano, in: El Cuaternario del País Valenciano, edited by: Grup Valencià Quaternari, University of Valencia, Valencia, 187-192, 1995b.

Viñals, M. J.: El Marjal Pego-Oliva. Evolución geomorfológica. Consejería de Agricultura y Medio Ambiente de la Generalitat Valenciana, Valencia, 352 pp., 1996.

15 Viñals, M. J. and Fumanal, M. P.: Quaternary development and evolution of the sedimentary environments in the central Mediterranean Spanish coast, Quatern. Int.., 29, 119-128, 1995.

Viñals, M. J., Mateu, G., Fumanal, M. P., Usera, J., and Favero, V.: Aportación al conocimiento de las facies lagunares y litorales de la Marjal de Oliva-Pego (Valencia), Cuaternario y Geomorfología, 3, 93-104, 1989.

20 Viso, A. C., Pesando, D., Bernard, P., and Marty, J. C.: Lipids components of the Mediterranean seagrass Posidonea Oceanica, Phytochemistry, 34, 381-387, 1993.

YII, E. I., Pantaleón-Cano, J., and Pérez-Obiol, R.: Análisis polínico de una secuencia holocénica en Roquetas de Mar (Almería), in: Trabajos de palinología básica y aplicada, Mateu, I., Dupré, M., Güemes, J., and Burgaz, M. E., Universidad de Valencia, Valencia, 189-198, 1994.

Zazo, C.: Interglacial sea levels, Quatern. Int., 55, 101-113, 1999.

Zazo, C., Goy, J. L., Dabrio, C. J., Bardají, T, Somoza, L., and Silva, P. G.: The last interglacial in the Mediterranean as a model for the present interglacial, Global Planet. Change, 7, 109117, 1993.

so Zazo, C., Goy, J. L., Dabrio, C. J., Bardají, T., Hillaire-Marcel, C., Ghaleb, B., González-Delgado, J. A., and Soler, V.: Pleistocene raised marine terraces of the Spanish Mediterranean and Atlantic coasts: records of coastal uplift, sea-level highstands and climate changes, Mar. Geol., 194, 103-133, 2003.

\section{CPD}

11, 3897-3936, 2015

\section{The MIS 5 \\ palaeoenvironmental record in the SE \\ Mediterranean coast}

T. Torres et al.

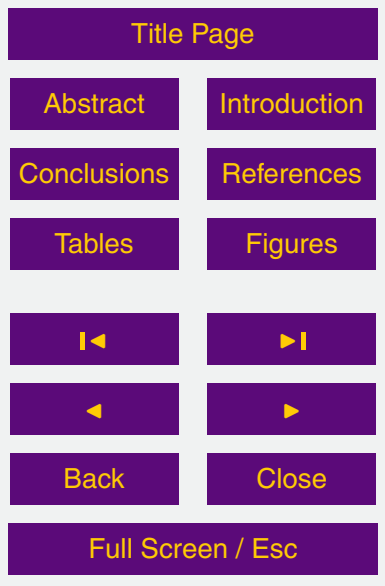

Printer-friendly Version

Interactive Discussion 
CPD

11, 3897-3936, 2015

The MIS 5

Table 1. Amino acid racemization ratios measured in the ostracod shells from the different horizons of Alfaix fluvial terraces and SRA borehole.

\begin{tabular}{llrrrr}
\hline Locality & Species & $\mathrm{N}$ & D/L Asp & D/L GLu & Age (ka) \\
\hline AFX-1 & C. torosa & 3 & 0.426 & 0.177 & $194.7 \pm 17.1$ \\
AFX-3 & C. torosa & 6 & $0.325 \pm 0.008$ & $0.202 \pm 0.030$ & $155.1 \pm 68.7$ \\
AFX-4 & C. torosa & 7 & $0.402 \pm 0.051$ & $0.214 \pm 0.058$ & $205.6 \pm 40.1$ \\
SRA2-300 & C. torosa & 2 & $0.268 \pm 0.008$ & $0.108 \pm 0.009$ & $72.3 \pm 25.6$ \\
SRA2-870 & C. torosa & 3 & $0.353 \pm 0.033$ & $0.128 \pm 0.049$ & $117.9 \pm 47.8$ \\
SRA2-900 & C. torosa & 3 & $0.363 \pm 0.035$ & $0.112 \pm 0.037$ & $156.5 \pm 4.8$ \\
SRA2-1050 & C. torosa & 5 & $0.342 \pm 0.044$ & $0.137 \pm 0.003$ & $136.6 \pm 45.3$ \\
SRA2-1200 & C. torosa & 7 & $0.344 \pm 0.023$ & $0.162 \pm 0.024$ & $139.5 \pm 35.9$ \\
SRA2-1380 & C. torosa & 7 & $0.381 \pm 0.011$ & $0.179 \pm 0.024$ & $168.0 \pm 28.6$ \\
SRA2-1500 & C. torosa & 14 & $0.349 \pm 0.021$ & $0.185 \pm 0.032$ & $156.7 \pm 48.4$ \\
& H. reptans & & & & \\
SRA2-1740 & C. torosa & 5 & $0.370 \pm 0.018$ & $0.133 \pm 0.036$ & $143.9 \pm 58.0$ \\
SRA2-1830 & C. torosa & 1 & 0.541 & 0.393 & $421.8 \pm 77.7$ \\
SRA2-2270 & C. torosa & 12 & $0.405 \pm 0.018$ & $0.275 \pm 0.062$ & $308.7 \pm 42.3$ \\
SRA2-2540 & C. torosa & 4 & $0.514 \pm 0.032$ & $0.235 \pm 0.035$ & $289.4 \pm 54.8$ \\
\hline
\end{tabular}


Table 2. Lithology observed in thin sections of resin-impregnated samples previously watersieved $(63 \mu)$.

\begin{tabular}{ll}
\hline Depth $(\mathrm{cm})$ & Lithology \\
\hline 400 & carbonates, tourmaline, clorite, zoisite, epidote, quartz. \\
\hline 900 & $\begin{array}{l}\text { zoisite, epidote, garnet, fragments of saussuritized rock, limestone, } \\
\text { calcite, quartz (sometimes with undulating extinction), opaque min- } \\
\text { erals and muscovite. }\end{array}$ \\
\hline 1500 & $\begin{array}{l}\text { quartz, zoisite, micaschist, quartzite, muscovite, biotite, saussuri- } \\
\text { tized plagioclase and opaque minerals (probably magnetite or pyrite) }\end{array}$ \\
\hline 1620 & $\begin{array}{l}\text { quartz, muscovite, biotite, clorite, limonitized rock fragments, tourma- } \\
\text { line, zoisite, quartzite and sandstone. }\end{array}$ \\
\hline 1960 & $\begin{array}{l}\text { quartz, limestone, micaschist, plagioclases, garnet, muscovite, mi- } \\
\text { caschist, opaque minerals, garnet, anfibol, anfibol and micaceous } \\
\text { quartzite. }\end{array}$ \\
\hline 2050 & $\begin{array}{l}\text { quartz, limestone, micaschist, plagioclases, garnet, muscovite, mi- } \\
\text { caschist, opaque minerals, garnet, anfibol, anfibol and micaceous } \\
\text { quartzite. }\end{array}$ \\
\hline $\begin{array}{l}\text { quartz, calcite, plagioclase, zoisite-epidote, garnet, muscovite, bi- } \\
\text { otite, clorite, cloritized biotite, sericite, tourmaline and fragments of } \\
\text { micaschist, quartzite and calcite. }\end{array}$ \\
\hline
\end{tabular}

CPD

11, 3897-3936, 2015

The MIS 5

palaeoenvironmental record in the SE Mediterranean coast

T. Torres et al.

\section{Title Page}

Abstract Introduction

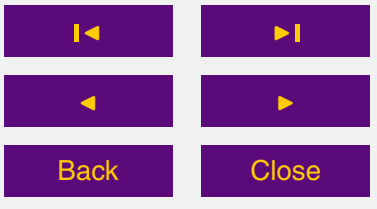

Full Screen / Esc

Printer-friendly Version

Interactive Discussion 
CPD

11, 3897-3936, 2015

Table 3. Lithology, fossil content and paleoenvironmental interpretation of Units and SubUnits identified in SRA borehole core (Au F: Autochthonous foraminifers; AI. F.: Allochthonous foraminifers).

\begin{tabular}{|c|c|c|c|c|c|}
\hline Units & Interval $(\mathrm{cm})$ & Sub-units & Lithology & Fossil content & $\begin{array}{l}\text { Paleoenvironmental inter- } \\
\text { pretation }\end{array}$ \\
\hline $\mathrm{V}$ & $300-0$ & & $\begin{array}{l}\text { brown fine-medium grained homometrical laminated sands (FI), with charcoal, } \\
\text { plant debris, seeds and pollen grains, some gypsum, gravel at the top }\end{array}$ & Al F, Au F at the top AF & $\begin{array}{l}\text { Alluvial with marine input at } \\
\text { its top }\end{array}$ \\
\hline \multirow[t]{8}{*}{ IV } & \multirow[t]{8}{*}{$1830-300$} & $\begin{array}{l}\text { IVj 520-280 } \\
\text { IVi 580-520 }\end{array}$ & $\begin{array}{l}\text { Brown-beige sandy/silty carbonate lutites } \mathrm{Fm}-\mathrm{Fs} \text {, angulous and homometrical } \\
\text { quartz grains, mica flakes abundant } \\
\text { Light gray carbonate lutites }\end{array}$ & $\begin{array}{l}\text { Al F, land snail, C. torosa } \\
\text { rare } \\
\text { Al F, rare Au F, brackish wa- } \\
\text { ter pelecipoda, land snails, } \\
\text { ostracods }\end{array}$ & $\begin{array}{l}\text { alluvial with small ponds } \\
\text { lagoon }\end{array}$ \\
\hline & & IVh 640-580 & Brown lutites with fine sand, lenticular gypsum & AlF & $\begin{array}{l}\text { distal deposits (lobe) pro- } \\
\text { grading alluvial }\end{array}$ \\
\hline & & $\begin{array}{l}\text { IVg } 700-640 \\
\text { IVf } 760-700\end{array}$ & $\begin{array}{l}\text { Silty clay (Fm) with lenticular gypsum. Fe patches } \\
\text { Interbeds of scarcely sandy lutites ( } F s \text { ) and lutitic sands (Sf), lenticular gypsum } \\
\text { from absent to very abundant, fine grained quartz and mica flakes. }\end{array}$ & $\begin{array}{l}\text { Au F } \\
\text { Al F }\end{array}$ & $\begin{array}{l}\text { lagoon } \\
\text { distal deposits (lobe) pro- } \\
\text { grading alluvial }\end{array}$ \\
\hline & & IVe $850-760$ & $\begin{array}{l}\text { (Myc). White carbonate lutites, gypsum very abundant (tabular and lenticular), } \\
\text { tubuli, quartz sand (rare). }\end{array}$ & Al F, Au F, ostracods & lagoon \\
\hline & & IVd 1240-850 & $\begin{array}{l}\text { white-light gray carbonate lutites (Myc; lutitic fraction accounts }>80 \% \text { ). Some } \\
\text { tabular gypsum ( }(1180 \text { and } 970 \text { ), charcoal (1090), mica flakes, and limonitized } \\
\text { tubuli }(940) \text {. At the top medium-fine grained quartz sand interbeds (Sf). }\end{array}$ & $\begin{array}{l}\text { Azoic,only a single level } \\
\text { with brackish water ostra- } \\
\text { cods }\end{array}$ & $\begin{array}{l}\text { frequently dried-up lagoon } \\
\text { with two alluvial ingres- } \\
\text { sions }\end{array}$ \\
\hline & & IVc $1420-1240$ & $\begin{array}{l}\text { beige, brown and gray lutites-Fm (lutitic fraction accounts }>80 \% \text { ). Iron oxides, } \\
\text { botroidal oxidized prite noduli. }\end{array}$ & $\begin{array}{l}\text { Al F, Au F, brackish water } \\
\text { pelecipoda, ostracods }\end{array}$ & lagoon-brackish waters \\
\hline & & $\mathrm{IVb} 1$ & fine gravel and sand (Gfs), botroidal limonite rare, rhizotubules rare & Rare Al F & alluvial fan toe \\
\hline & & IVa $1830-1540$ & $\begin{array}{l}\text { Green and grey marls-Myc facies (lutitic fraction accounts }>90 \% \text { ), angulous fine } \\
\text { grained quartz and mica flakes, limonitized root casts. Tabular gypsum rare }\end{array}$ & Rare Al F, rare Au F (1740) & $\begin{array}{l}\text { mud flat playa/margin playa } \\
\text { lake }\end{array}$ \\
\hline III & $2360-1830$ & & $\begin{array}{l}\text { Lutitic sands. Fs (lutitic fraction> } 60 \% \text { in all samples). Sands are medium-fine } \\
\text { grained and made of quartz, mica flakes abundant. Two Mc interbeds ( } 2300- \\
2270 \text { and } 1830-1820 \text { ) contained well preserved autochthonous ostracods. }\end{array}$ & Abundant Al F & $\begin{array}{l}\text { fan toe/mud flat deposits. } \\
\text { Two short palustrine events }\end{array}$ \\
\hline II & $2840-2360$ & & $\begin{array}{l}\text { Gm though poorly recovered. Polymictic gravel (metamorphic, dolostone, quartz), } \\
\text { C: } 20-60 \mathrm{~mm} \text {, with coarse quartz sand, limonitized root casts, mica flakes abun- } \\
\text { dant. }\end{array}$ & AlF & $\begin{array}{l}\text { Alluvial fan (channel?) de- } \\
\text { posits }\end{array}$ \\
\hline 1 & $2960-2840$ & & $\begin{array}{l}\text { Carbonate lutites, with very fine grained quartz grains and mica flakes, Fe stains, } \\
\text { botroidal limonite (former pyrite), bioclasts (forams) very abundant }\end{array}$ & AlF & deep marine environment \\
\hline
\end{tabular}

Note: Au F: Authochtonous foraminifers; Al. F.: Allochthosnous foraminifers.

\section{The MIS 5 \\ palaeoenvironmental record in the SE Mediterranean coast}

T. Torres et al.

\section{Title Page}

Abstract

Introduction

Conclusions

References

Tables

Figures
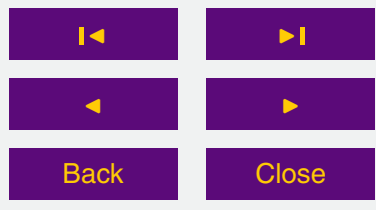

Full Screen / Esc

Printer-friendly Version

Interactive Discussion 


\section{CPD}

Table 4. Information provided by the $n$-alkane ratios.

\begin{tabular}{|c|c|}
\hline n-Alkane ratio & Information provided \\
\hline Predominant $n$-alkane chain & $\begin{array}{l}\text { Provides information of the origin of the biomolecules: phyto- } \\
\text { plankton and algae are dominated by low molecular weight com- } \\
\text { pounds, maximizing at } C_{17} \text { (Gelpi et al., 1970; Blumer et al., } \\
1971 \text {; Cranwell et al., } 1987 \text { ); submerged and floating macro- } \\
\text { phytes maximize at } C_{21-25} \text { (Cranwell, } 1984 \text {; Ogura et al.1990; } \\
\text { Viso et al. 1993), high molecular weight } n \text {-alkanes }\left(>C_{25} \text { ) are }\right. \\
\text { typical of terrestrial vascular plants (Cranwell et al., } 1987) \text {. }\end{array}$ \\
\hline Average chain length & $\begin{array}{l}\text { Indicates the origin of biomarkers: phytoplankton and algae have } \\
\text { lower number of carbon atoms in the } n \text {-alkane molecules (Gelpi } \\
\text { et al., } 1970 \text {; Cranwell et al., 1987); submerged/floating macro- } \\
\text { phytes maximize at } C_{21}, C_{23} \text { and } C_{25} \text {; terrestrial vascular plants } \\
\text { maximize in }>C_{25} \text { (Cranwell et al., 1987). }\end{array}$ \\
\hline $\begin{array}{l}\text { Aquatic proxy (Paq) } \\
\left(\mathrm{C}_{23}+\mathrm{C}_{25}\right) /\left(\mathrm{C}_{23}+\mathrm{C}_{25}+\mathrm{C}_{29}+\mathrm{C}_{31}\right)\end{array}$ & $\begin{array}{l}\text { Reflects the input of submerged/floating aquatic macrophytes } \\
\text { relative to emergent and terrestrial plant input (Ficken et al., } \\
2000 \text { ). Paq }<0.1 \text { is linked to a dominant contribution of terrestrial } \\
\text { plants; Paq }=0.1-0.4 \text { marks a marked development of emer- } \\
\text { gent macrophytes; Paq }>0.4 \text { indicates a dominant input of sub- } \\
\text { merged and floating macrophytes. }\end{array}$ \\
\hline $\begin{array}{l}\text { Terrigenous/Aquatic Ratio } \\
\text { of hydrocarbons } \\
\left(\mathrm{TAR}_{\mathrm{HC}}\right)=\mathrm{C}_{27}+\mathrm{C}_{29}+\mathrm{C}_{31} /\left(\mathrm{C}_{15}+\mathrm{C}_{17}+\mathrm{C}_{19}\right)\end{array}$ & $\begin{array}{l}\text { Reflects the input of terrestrial plants relative to algae input (Sil- } \\
\text { liman et al., 1996). } \\
\text { ) }\end{array}$ \\
\hline $\begin{array}{l}\text { Relative percentage of } C_{31} n \text {-alkane } \\
\text { with respect to the sum } C_{27}+C_{29}+C_{31}\end{array}$ & $\begin{array}{l}\text { Large amounts of } \mathrm{C}_{31} \text { in sediments are associated with dry } \\
\text { phases and extensive grass cover and pines (Schwarcz et al., } \\
\text { 2002; Ortiz et al., 2010; Torres et al., 2013) }\end{array}$ \\
\hline
\end{tabular}

\section{The MIS 5 \\ palaeoenvironmental record in the SE Mediterranean coast}

T. Torres et al.

\section{Title Page}

Abstract

Introduction

Conclusions

References

Tables

Figures

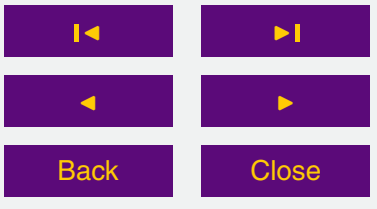

Full Screen / Esc

Printer-friendly Version

Interactive Discussion 


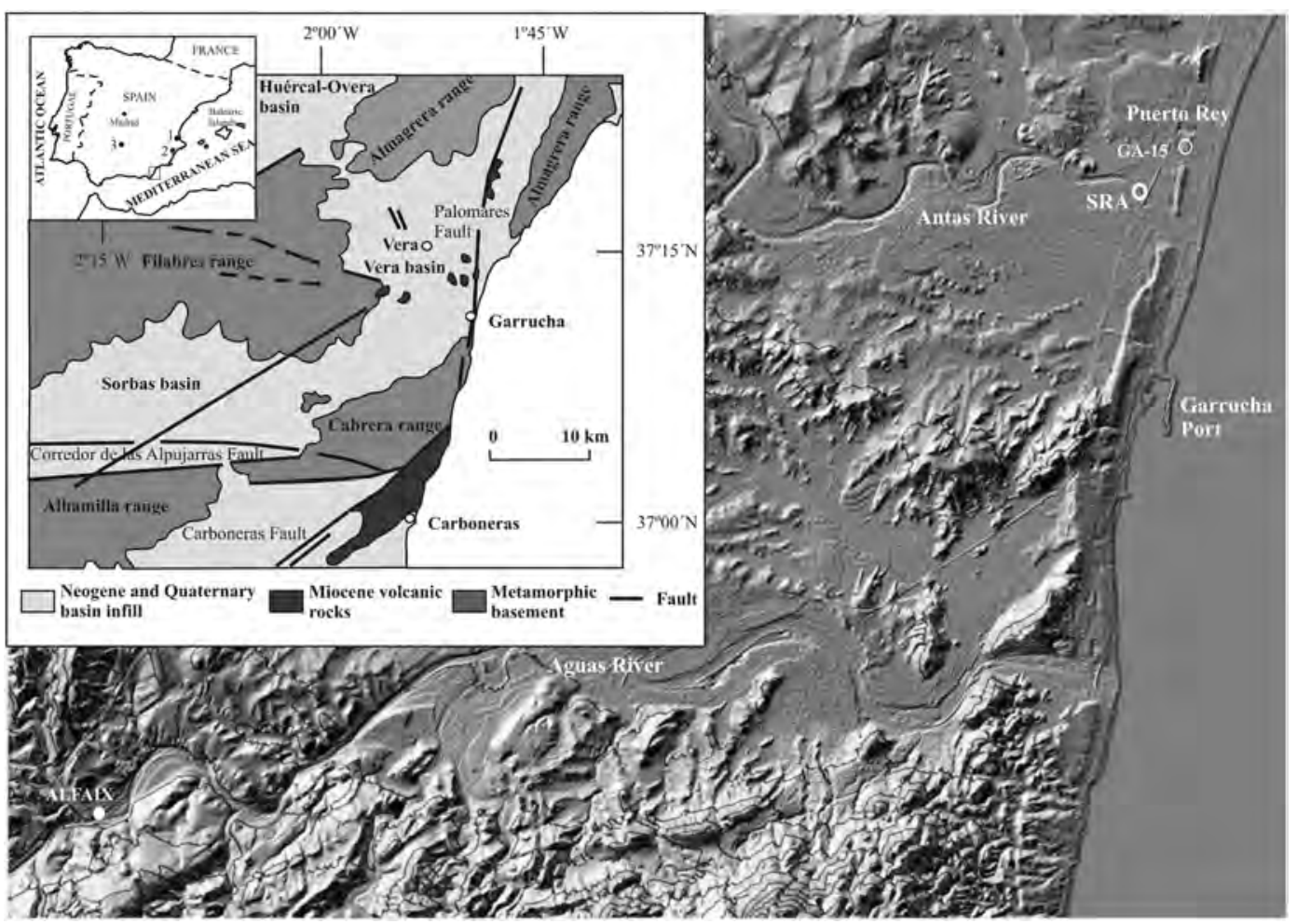

Figure 1. Geographical and Geological setting with the position of the localities. Other localities cited in the paper are also shown (1-Pego Basin; 2-Elche Basin; 3-Fuentillejo).

\section{CPD}

11, 3897-3936, 2015

The MIS 5

palaeoenvironmental record in the SE

\section{Mediterranean coast}

T. Torres et al.

\section{Title Page}

Abstract

Introduction

Conclusions

References

Tables

Figures

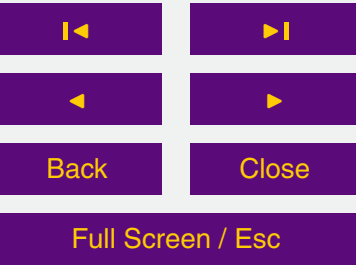

Printer-friendly Version

Interactive Discussion 


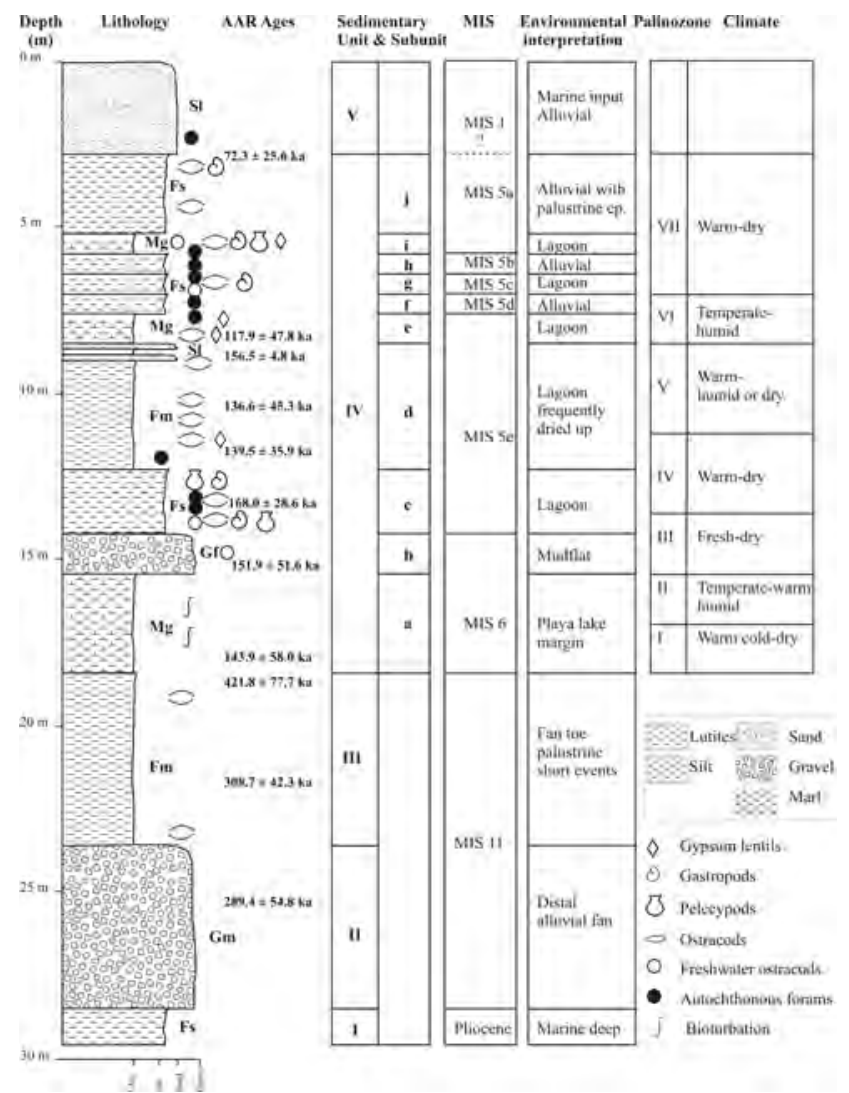

Figure 2. Stratigraphy and chronology of SRA core with the different sedimentological, micropaleontological and palinological units defined together with the palaeoenvieronmental and palaeoclimatological interpretation.

\section{CPD}

11, 3897-3936, 2015

The MIS 5

palaeoenvironmental record in the SE

\section{Mediterranean coast}

T. Torres et al.

\section{Title Page}

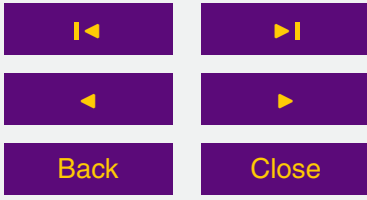

Full Screen / Esc

Printer-friendly Version

Interactive Discussion 

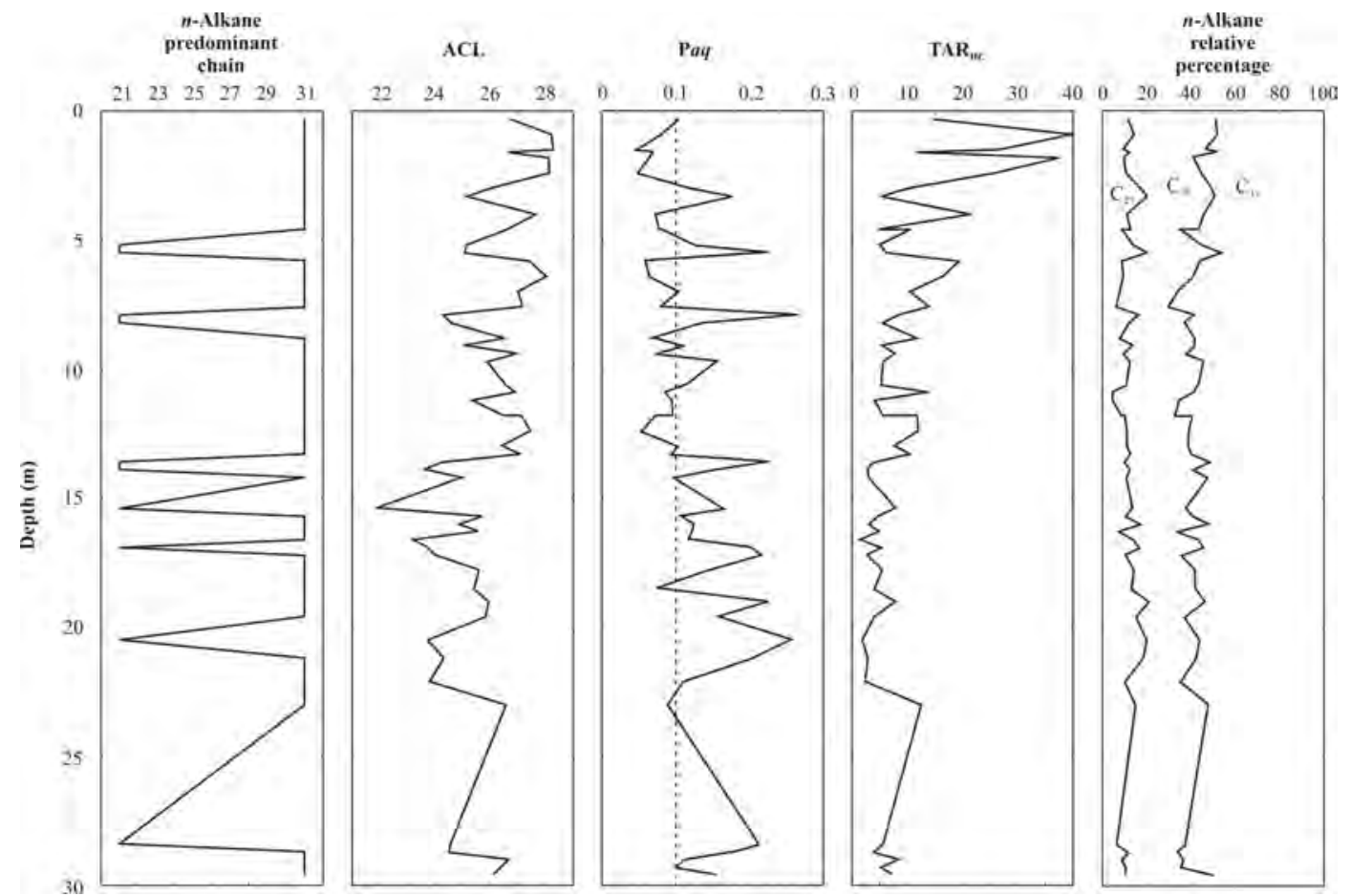

Figure 3. Profiles of the $n$-alkane predominant chain, $\mathrm{ACL}, \mathrm{Paq}$ index, $\mathrm{TAR}_{\mathrm{HC}}$ and the relative percentages of $\mathrm{C}_{27}, \mathrm{C}_{29}$ and $\mathrm{C}_{31}$ with respect to the sum $\mathrm{C}_{27}+\mathrm{C}_{29}+\mathrm{C}_{31}$ in SRA core.

CPD

11, 3897-3936, 2015

The MIS 5

palaeoenvironmental record in the SE

Mediterranean coast

T. Torres et al.

Title Page

Abstract

Introduction

Conclusions

References

Tables

Figures

14

4

Back

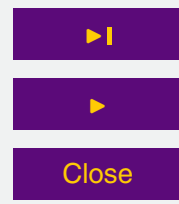

Full Screen / Esc

Printer-friendly Version

Interactive Discussion 


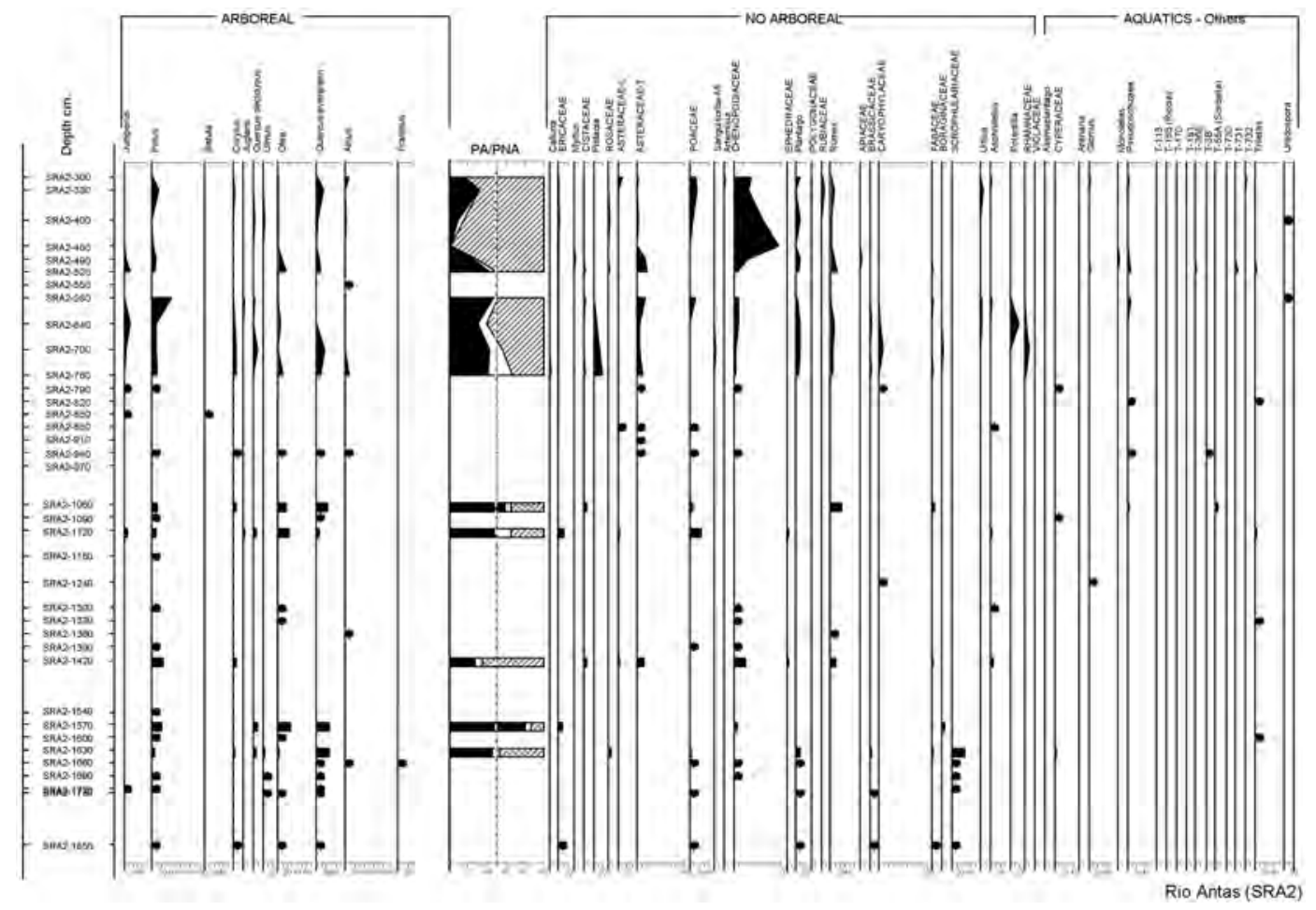

CPD

11, 3897-3936, 2015

The MIS 5

palaeoenvironmental record in the SE

Mediterranean coast

T. Torres et al.

Title Page

Abstract

Introduction

Conclusions References

Tables

Figures

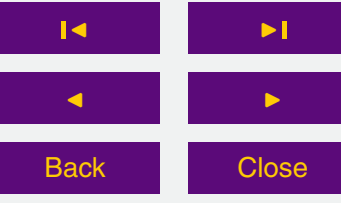

Full Screen / Esc

Figure 4. Pollen diagram of SRA core.

Printer-friendly Version

Interactive Discussion

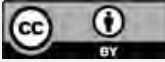



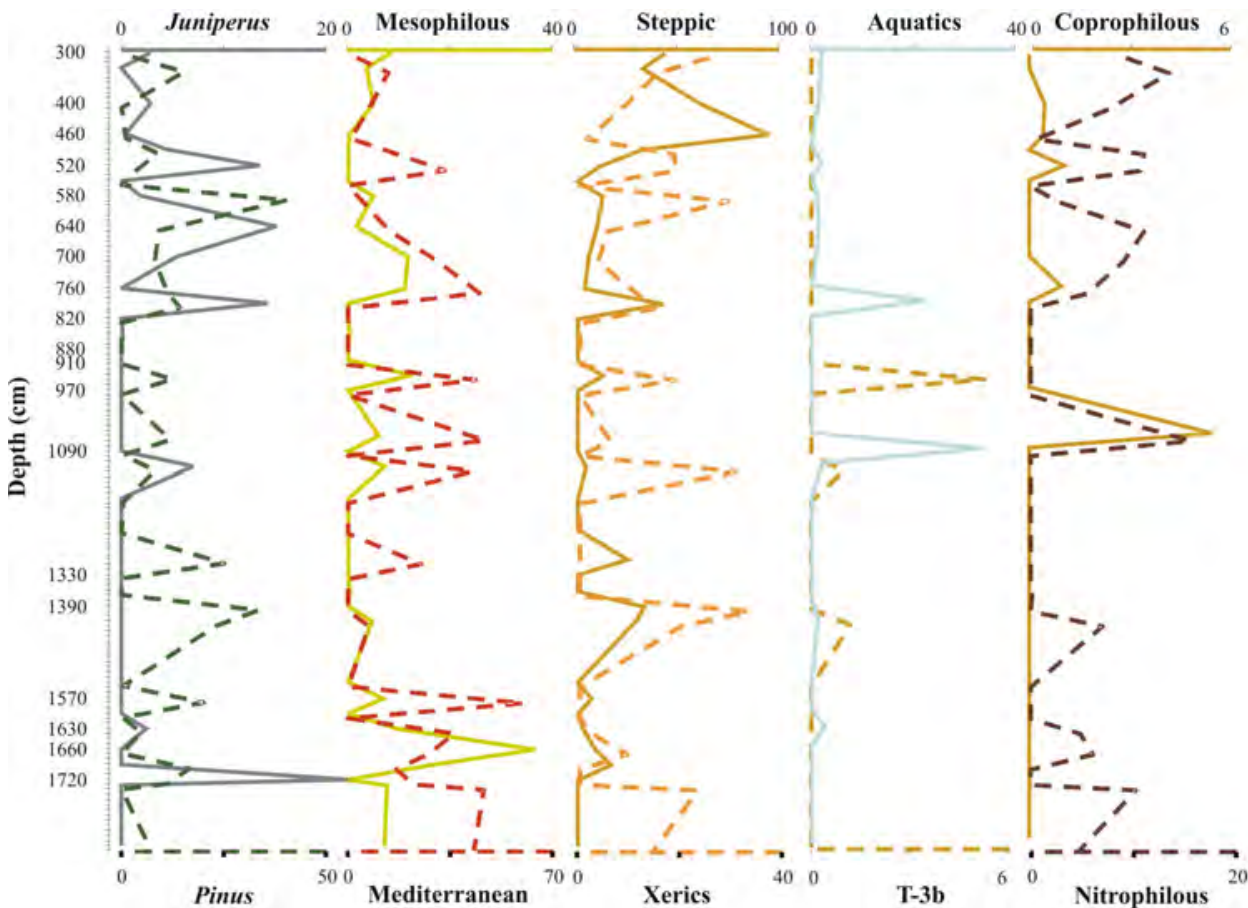

Palinozone

CPD

11, 3897-3936, 2015

The MIS 5

palaeoenvironmental record in the SE Mediterranean coast

T. Torres et al.

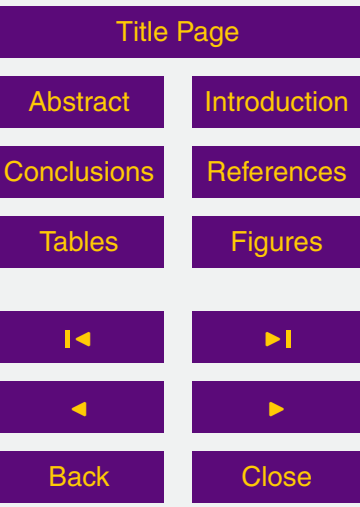

Full Screen / Esc

Figure 5. Synthetic pollen diagram of SRA core.

Printer-friendly Version

Interactive Discussion

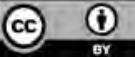




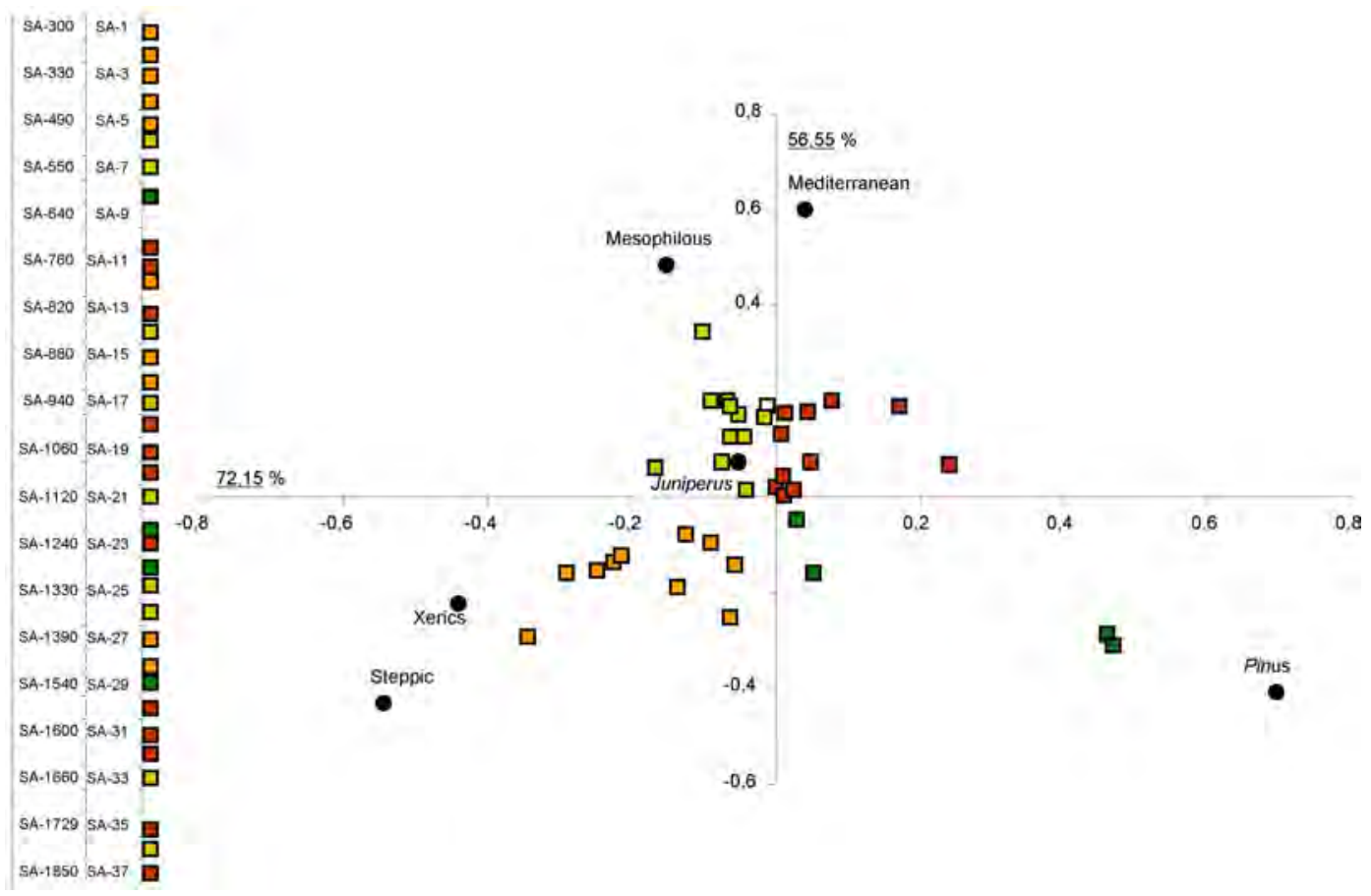

\section{CPD}

11, 3897-3936, 2015

The MIS 5

palaeoenvironmental record in the SE Mediterranean coast

T. Torres et al.

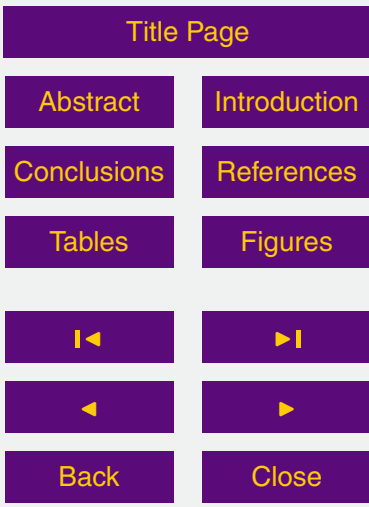

Full Screen / Esc

Figure 6. Principal component analysis of the pollen content in SRA core.

Printer-friendly Version

Interactive Discussion 